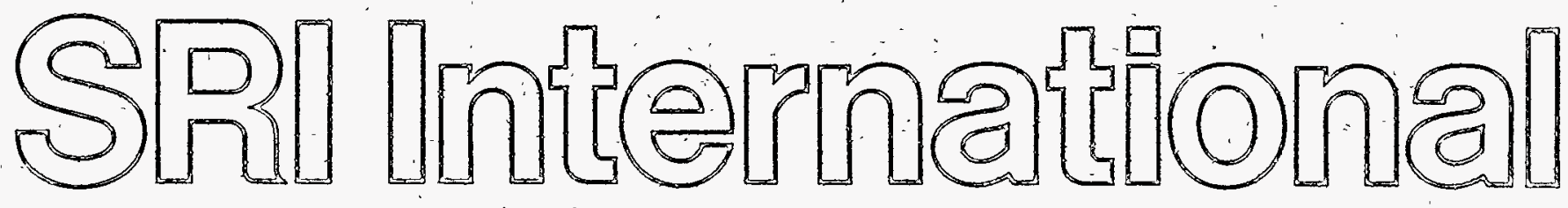

Phase I Final Report - 22 March 1995

\title{
HIGHLY DISPERSED CATALYSTS FOR COAL LIQUEFACTION
}

By: Albert S. Hirschon and Robert B. Wilson

SRI Intemational

Omar Ghaly

Bechtel Corporation

SRI Project 2760

Period Covering August 23, 1994, through November 22, 1994

Prepared for:

United States Department of Energy

Pittsburgh Energy Technology Center

P.O. Box 10940

Pittsburgh, PA 15236

Contract No. DE-AC22-91PC91039
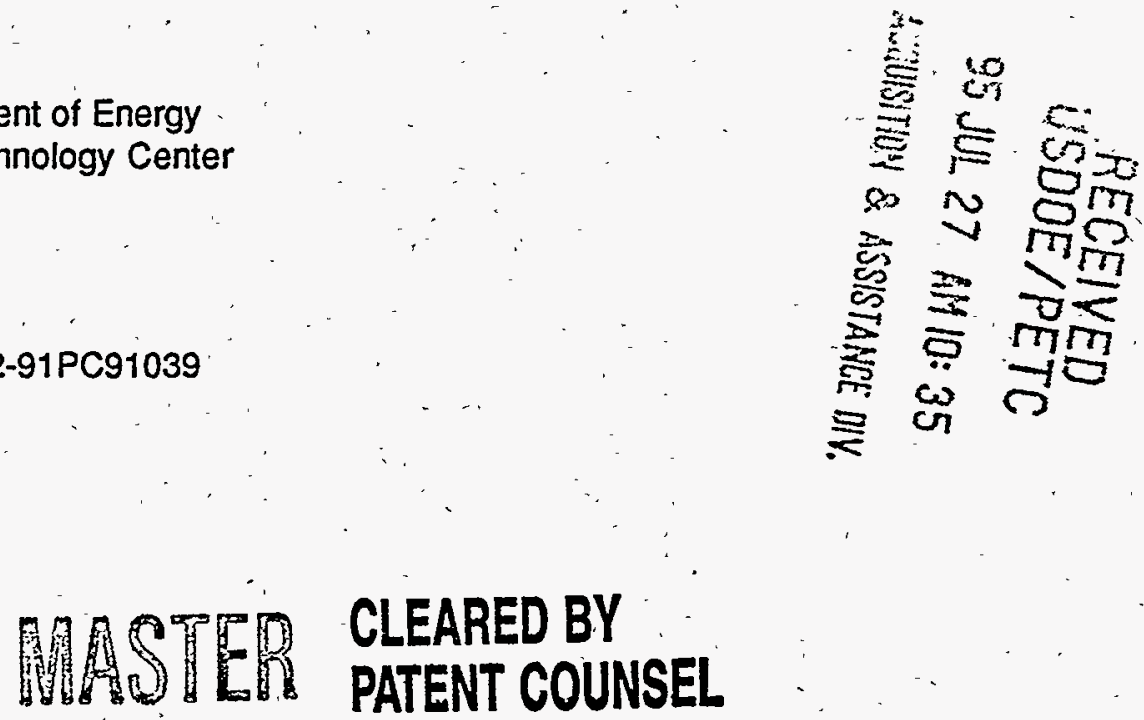


\section{SUMMARY}

This Phase I final report summarizes the results of our research under Contract No. DEAC22-91PC91039, Highly Dispersed Catalysts for Coal Liquefaction. The ultimate goal of this project is to develop novel processes for making the conversion of coal into distillable liquids competitive to that of petroleum products in the range of $\$ 25 / \mathrm{bbl}$. The objectives of Phase I were to determine the utility of new precursors to highly dispersed catalysts for use of syngas atmospheres in coal liquefaction, and to estimate the effect of such implementation on the cost of the final product. The project is divided into three technical tasks. Tasks 1 and 2 are the analyses and liquefaction experiments, respectively, and Task 3 deals with the economic effects of using these methods during coal liquefaction.

\section{TASK 1. ANALYTICAL SUPPORT}

This task supports Task 2 by analyzing the liquefaction products and catalysts involved in the liquefaction runs. The typical analytic techniques included analysis of light gases and fractionation of the products after the coal liquefaction experiments. The fractionation included solvent fractionation for the screening experiments and use of an ASTM distillation apparatus for the simulated two-stage liquefaction experiment. Elemental analyses were obtained as necessary.

\section{TASK 2. LABORATORY-SCALE OPERATION}

Three types of laboratory-scale conversions were investigated during this phase. In the first type of conversion various ranks of coals and catalysts were compared for extents of conversion in synthetic solvents, including an inert solvent such as hexadecane. This method allowed us to better compare our catalysts without the distraction of solvent initiated chemistry. Experiments using this method clearly showed that our method of using designed catalyst precursors gives good conversion yields, even in the absence of a good donor solvent. Furthermore, evidence from our work show that these catalysts may help the coal liquefaction by reducing the amount of retrogressive reactions, thus leaving a better quality product.

The second type of experiments conducted during Phase I were screening tests in which we compared various types of catalysts and conversion atmospheres for converting a Black Thunder coal and corresponding recycle vehicle. We looked at these screening tests as the equivalent of the 
first stage of the two-stage liquefaction process. Our efforts in this phase of the project focused on these first stage screening tests. We found that, under hydrogen atmospheres, the most effective iron catalysts were the carbonyl irons in the order iron carbonyl $=$ thiolato iron carbonyl $\gg$ sulfated iron oxide > iron oxide. When syngas was used as the conversion atmosphere, the reactivity order was found to be thiolato iron $\gg$ iron carbonyl. In comparing the molybdenum catalysts, we found that the thiolato molybdenum $\gg$ MolyVanL, and the MolyVanL functioned equally well under syngas atmospheres or hydrogen atmospheres. The thiolato molybdenum was not tested under syngas atmospheres, but would be assumed to be equally active. A nickel catalyst was also investigated and was found to be a very good catalyst for low rank coals and also very good under syngas atmospheres.

The third type of investigation was a simulated two-stage liquefaction experiment. We developed a prototype reactor system in which a high pressure syringe pump could inject a hydrotreating catalyst slurry into the reactor at reaction pressures and temperatures. Thus, rather than pumping the first-stage reaction components into a second-stage reactor filled with the hydrotreating catalyst, we added the hydrotreating catalyst directly into the first stage reactor. To test this system, we conducted a conversion using MolyVanL as a catalyst under a $\mathrm{H}_{2}$ atmosphere, and we found that the test was successful. For comparison, we also conducted the conversion under $\mathrm{CO} / \mathrm{H}_{2}$ atmospheres for both first and second stage as well as under $\mathrm{CO} / \mathrm{H}_{2}$ atmospheres for first stage and $\mathrm{H}_{2}$ atmospheres for second stage. Direct injection was not used in the latter two cases because of the requirement for changing gases. We found that the highest conversions were achieved when $\mathrm{H}_{2}$ was used for both stages of the conversion and when a $\mathrm{CO} / \mathrm{H}_{2}$ atmosphere was used for the first stage and a $\mathrm{H}_{2}$ atmosphere was used in the second stage, with slightly higher conversions found in the latter, syngas case. However, much poorer conversions were achieved when syngas was used in the final or upgrading case, most likely because the hydrogenation activity of the hydrotreating catalyst was not fully exploited under these processing conditions.

\section{TASK 3. TECHNICAL ASSESSMENT}

The data obtained from a baseline simulated two-stage liquefaction process was evaluated by Bechtel for a preliminary economic assessment and to identify opportunities for potential improvement. These data were evaluated assuming known plant configurations using a dispersedcatalyst slurry reactor and an ebullated bed reactor in series. This baseline experiment was conducted using a MolyVanL catalyst, which although we found to be an excellent catalyst, was not as good as our thiolato catalysts. With the MolyVanL catalyst, lower pressures were required 
than used during other 2-stage liquefaction runs. The analysis identified several areas where our catalysts will likely allow improvement over current practices, but testing on a continuous benchscale unit will be required to confirm these assessments. 


\section{CONTENTS}

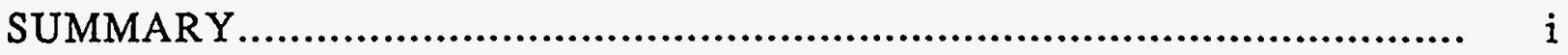

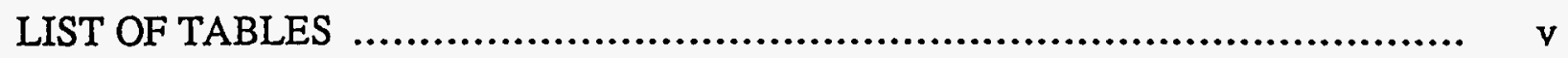

INTRODUCTION .................................................................. 1

TASK 1: ANALYTICAL SUPPORT .............................................. 3

Screening Tests........................................................................ 3

Second-Stage Conversions................................................................... 5

TASK 2: LABORATORY-SCALE OPERATIONS ..................................... 7

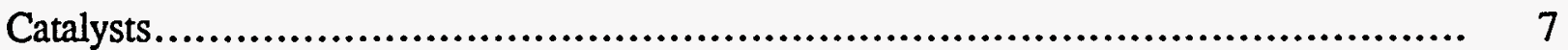

Coal Conversion in Synthetic Solvents............................................................ 7

Black Thunder Screening Studies................................................................ 10

Two-Stage Liquefaction Experiments .................................................... 13

TASK 3: TECHNICAL AND ECONOMIC ASSESSMENT.......................... 18

Commercial Liquefaction Plant Description............................................... 18

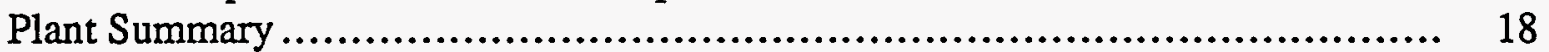

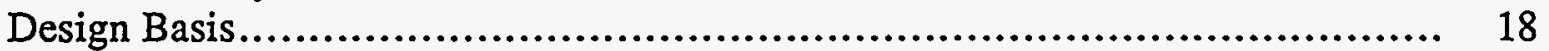

Process Description............................................................ 19

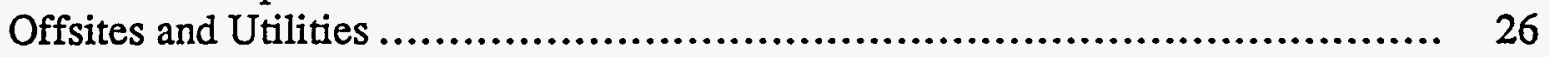

Liquefaction Plant Cost ........................................................ 26

Cost Estimate Basis ............................................................ 26

Installed Plant Capital Cost....................................................... 28

Economic Analysis .............................................................. 30

Product Price for the Base Case............................................... $\quad 32$

Economics Sensitivity ...................................................... 32

Economic Evaluation of Syngas Case ........................................ 33

FUTURE WORK ............................................................... 34

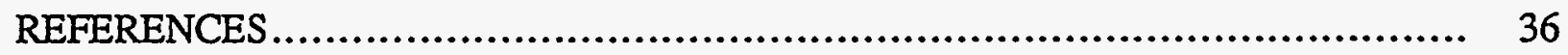




\section{LIST OF TABLES}

1 Analyses of Black Thunder Coal and Recycle Solvent ......................... 3

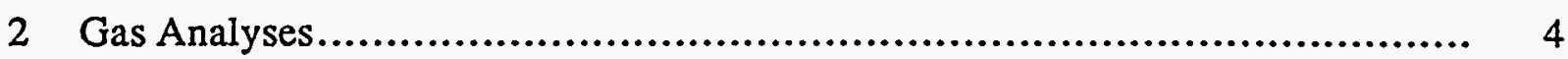

3 Gas Analyses............................................................... 6

4 Conversion to Toluene-Soluble Products in Hexadecane........................... 9

5 DAF Yields of Fractionated Products Using Iron Catalysts......................... 12

6 Effect of Catalysts on CO Utilization............................................... 12

7 DAF Yields Molybdenum Catalysts................................................... 14

8 DAF Yields of Using Various Metal Catalysts ................................. 14

9 Analyses of Recycle Vehicle Distillation Fractions ............................. 16

10 Analyses of Distillation Products for $\mathrm{H}_{2} / \mathrm{H}_{2}$ Conversion........................ 16

11 Analyses of Distillation Products for $\mathrm{CO} / \mathrm{H}_{2}$ First-Stage $\mathrm{H}_{2}$ Second-Stage Conversion .......................................................... 17

12 Major Design Criteria and Considerations....................................... 20

13 Major Process Streams Summary ........................................... 22

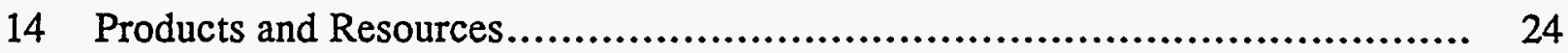

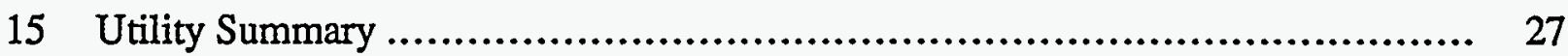

16 Installed Plant Capital Cost for Base Case ..................................... 29

17 Key Cost and Financial Parameters and Assumptions................................. 31

17 Economic Analysis Results ....................................................... 33 


\section{INTRODUCTION}

Integrated processes for liquefying coal have evolved to the current multistage close coupled catalytic configurations. ${ }^{1-4}$ Recent estimates (1990) indicate that two-stage conversion of coal to liquids has a product cost of about $\$ 38$ per barrel and that the improved quality of the liquids makes them equivalent to oil costing $\$ 33$ per barrel. Several areas in the conversion technology have been identified that, if improved, should make coal converted to oil more cost competitive with petroleum products. These areas include pretreatment and cleaning methods, choice of feedstock, novel catalysts, and processes for improving hydrocarbon recovery. The objective of this project is to address possible methods of improving the efficiency of these and other steps in the integrated process so that the overall conversion will show increased cost effectiveness. Phase I concentrated on individual steps and technoeconomic evaluations to provide information on their relative effectiveness toward the overall goal of $\$ 25$ per barrel.

Most previous work has concentrated on bituminous coals, which are much easier to convert than lower-rank coals such as subbituminous coals and lignites. ${ }^{5}$ The lower-rank coals are more abundant and cheaper, and conversions lead to a higher quality product with less heteroatom content. ${ }^{6}$ However, the yield of liquid products is low. The low conversion rates of these coals has been attributed to their high oxygen content, and the carboxyl groups are thought to cause retrograde reactions by free radical processes. 7,8 Additionally, phenolics often are associated with retrograde reactions, leading to polymeric furans. 9,10 Developing a process for using these coals in high conversions would greatly improve the economics of coal conversion. Several approaches, including highly dispersed catalysts and coal pretreatment techniques, have been suggested to overcome these detrimental reactions. In recent work we studied both these approaches to enhance the convertibility of coal and minimize the retrogressive reactions.

This project is designed to evaluate the feasibility of using low-rank coals such as Wyodak and lignite in a two-stage liquefaction pilot demonstration unit (PDU). The primary objectives are to

- Synthesize and impregnate coal with high activity, highly dispersed catalysts or catalysts precursors (dispersed on the molecular scale) 
- Develop an understanding of these catalysts in terms of their activities for hydrogenation and hydrogenolysis, especially in terms of removing phenolics and carboxylates, which are thought to cause most retrogressive reactions

- Monitor the activities and physical properties of these catalysts during coal liquefaction and compare them with those of other types of catalysts; and

- Evaluate process cost improvements that might be realized through the use of low-rank coals, dispersed catalysts, and $\mathrm{CO} / \mathrm{H}_{2}$ for coal liquefaction in a twostage close-coupled configuration. 


\section{TASK 1: ANALYTICAL SUPPORT}

The objectives of this task were to provide analytical support for the laboratory conversion studies conducted in Task 2 . We used this analytical support to assess any differences in the reactivities and selectivities of the catalysts and the effect of variations in process conditions such as syngas atmospheres. Elemental analyses were conducted routinely. The results for the simulated two-stage liquefaction experiments are presented along with the yields in the section on Task 2. The majority of the coal conversions conducted during this project utilized Black Thunder coal and the corresponding recycle vehicle. The analyses of these materials are shown below in Table 1.

Table 1. Analyses of Black Thunder Coal and Recycle Solvent

\begin{tabular}{lccc}
\hline $\begin{array}{l}\text { Ulimate Analysis } \\
\text { (Wt\%) }\end{array}$ & $\begin{array}{c}\text { Black Thunder } \\
\text { (As Received) }\end{array}$ & $\begin{array}{c}\text { Black Thunder } \\
\text { (Dried at 76 })\end{array}$ & Recycle Solvent \\
Carbon & 55.07 & 63.56 & 88.08 \\
Hydrogen & 6.22 & 0.96 & 7.09 \\
Nitrogen & 0.79 & 0.80 & 0.99 \\
Sulfur & 0.34 & & \\
Chlorine & $<0.07$ & & \\
Ash & 5.87 & & \\
Oxygen (by diff) & 31.71 & & \\
Proximate Analysis & & & \\
(Wt\% As Received) & $:$ & & \\
Moisture & 21.21 & & \\
Volatile Moisture & 35.30 & & \\
Ash & 5.87 & \\
\hline
\end{tabular}

\section{SCREENING TESTS}

Table 2 presents the gas analyses of the liquefaction experiments for the screening tests, which were used to determine differences as a function of catalyst and process conditions such as syngas atmospheres. These gas analyses were obtained from the conversions using various 
Table 2

GAS ANALYSESa

\begin{tabular}{lrrrrrr}
\multicolumn{1}{c}{ Catalyst } & $\mathrm{CO}_{2}$ & $\mathrm{CO}$ & $\mathrm{CH}_{4}$ & $\mathrm{C}_{2} \mathrm{H}_{6}$ & $\mathrm{C3}$ & atm \\
\hline Recycle only & - & - & 67 & 28 & 16 & $1000 \mathrm{psi} \mathrm{H}_{2}$ \\
$\mathrm{Fe}(\mathrm{CO})_{5}$ & 69 & 17 & 79 & 27 & 10 & $1000 \mathrm{psi} \mathrm{H}$ \\
$\mathrm{Fe}(\mathrm{CO})_{5}$ & 220 & 200 & 116 & 38 & 13 & $50 \% \mathrm{CO}$ \\
MoVanL & 30 & 10 & 109 & 36 & 12 & $1000 \mathrm{psi} \mathrm{H}$ \\
MoVanL & 197 & 67 & 101 & 33 & 9 & $50 \% \mathrm{CO}$ \\
$\mathrm{Ni}(\mathrm{COD})_{2}$ & 33 & $\mathrm{ND}$ & 97 & 34 & 7 & $1000 \mathrm{psi} \mathrm{H}_{2}$ \\
$\mathrm{Ni}_{(}(\mathrm{COD})_{2}$ & 87 & 17 & 85 & 29 & 7 & $50 \% \mathrm{CO}$ \\
$\mathrm{Fe}_{2} \mathrm{~S}_{2}(\mathrm{CO})_{6}$ & 45 & $\mathrm{ND}$ & 98 & 33 & 7 & $1000 \mathrm{psi} \mathrm{H}$ \\
$\mathrm{Fe}_{2} \mathrm{~S}_{2}(\mathrm{CO})_{6}$ & 167 & 51 & 96 & 30 & $\mathrm{ND}$ & $50 \% \mathrm{CO}$ \\
\hline
\end{tabular}

aReaction conducted in $300 \mathrm{~mL}$ autoclave, $425^{\circ} \mathrm{C}, 1000$ psig pressure cold. Gases reported in mmol.

catalysts such as iron carbonyl, thiolato iron carbonyl, MolyVanL, and nickel cyclooctadiene. All these catalysts were compared using both hydrogen atmospheres and hydrogen/carbon monoxide atmospheres.

The presence of carbon monoxide during these reactions caused no notable increase in methane or higher hydrocarbon contents, suggesting no significant methanation reactions or Fischer-Tropsch type chemistry. The extent of carbon monoxide utilization can be estimated from the conversion to carbon dioxide. The carbon monoxide could be converted to carbon dioxide by the conventional water-gas-shift reaction, or the carbon monoxide could react with oxygen functionalities in the coal such as phenolics to produce carbon dioxide. The latter route is preferred because it would reduce the oxygen functionalities in coal, which are most likely associated with retrogressive reactions. As seen in Table 2, the carbon monoxide conversion was only nominal when using iron carbonyl as a catalyst, with the $\mathrm{CO}_{2} / \mathrm{CO}$ ratio of only 1.1 . In contrast, the thiolato iron carbonyl catalyzed reactions were substantially more effective in utilization of the carbon monoxide, with a $3.3 \mathrm{CO}_{2}$-to- $\mathrm{CO}$ ratio, consistent with the increased coal conversions with this 
catalyst (Table 4 in Task 2). The MolyVanL syngas conversions likewise showed high carbon monoxide utilization, with a $\mathrm{CO}_{2} / \mathrm{CO}$ ratio of 3.3, while the nickel-catalyzed coal conversions showed the highest activity with a ratio of 5.0. However, in this case the low amount of carbon oxides found in the product gases suggest that some of the carbon monoxide may have been incorporated into the liquid products.

\section{SECOND-STAGE CONVERSIONS}

The data shown in Table 3 illustrate the light gas production for the two-stage liquefaction runs using a Black Thunder coal and recycle vehicle. The coal was first subjected to a dispersed catalyst at $425^{\circ} \mathrm{C}$ and then to a hydrotreating catalyst at $400^{\circ} \mathrm{C}$. This simulated two-stage conversion was conducted in a 1-L autoclave with a cold pressure of $1200 \mathrm{psia}$, whereas the previous runs were conducted in a 300-mL autoclave with 1000-psia pressure. Table 3 lists gas analyses obtained from these various conversions. When hydrogen was used in the first-stage conversion, the run is referred to as MoVanL-B1, and the second-stage upgrading run is referred to as MoVanL-B2. In a similar way the conversion using syngas $\left(50 \% \mathrm{CO} / \mathrm{H}_{2}\right)$ first stage is referred to as MoVanL-C1, and the second stage using hydrogen atmosphere is referred to as MoVanL-C2. For comparison with this simulated two-stage run, data from previous runs where no hydrotreating catalyst was used are also listed in Table 3. For instance, the conversion of recycle vehicle without coal and conversions using MolyVanL, coal, and recycle vehicle, are referred to as MoVanL-A. The amount of the various gases have been normalized to the amount of coal/recycle vehicle fed to compare conversions that use different amounts of feed.

As seen from the gas analyses in Table 3, both the recycle vehicle and the coal produce methane and light gases. The amount of methane per gram of feed produced for the recycle vehicle was found to be $1.34 \mathrm{mmol}$ methane/gram feed, compared to $1.56 \mathrm{mmol}$ methane/gram for the coal plus recycle conversion. These values were found to be typical of all conversions conducted in the 300-mL reactor using these highly dispersed catalysts, whether they were based on iron, nickel, or molybdenum based. However, as seen for the 1-L reactor, MolyVanL-B1, the methane production is reduced to $0.60 \mathrm{mmol}$ methane/gram of feed. Likewise, fewer $C_{2}$ and $C_{3}$ hydrocarbons are observed in the gas slate for the conversion in the 1 -L reactor. The major difference between these two reactor systems is the hydrogen-to-feed ratio, which is $9.8 \mathrm{mmol}$ $\mathrm{H}_{2} / \mathrm{g}$ feed for the smaller $300-\mathrm{mL}$ autoclave and $12.8 \mathrm{mmol} / \mathrm{g}$ feed for the 1 liter autoclave. Thus the conversion in the 1 liter reactor has more hydrogen available and most likely undergoes fewer retrogressive reactions and produces less coke and light gases. Likewise, as seen in MoVanL-C1 
Table 3

GAS ANALYSESa

\begin{tabular}{|c|c|c|c|c|c|c|}
\hline Catalyst & $\mathrm{CO}_{2}$ & $\mathrm{CO}$ & $\mathrm{CH}_{4}$ & $\mathrm{C}_{2} \mathrm{H}_{6}$ & C3 & atm \\
\hline Recycle onlyb & - & - & 1.34 & 0.56 & 0.32 & $1000 \mathrm{psi} \mathrm{H}_{2}$ \\
\hline MoVanL-A ${ }^{b}$ & 0.43 & 0.14 & 1.56 & 0.51 & 0.17 & $1000 \mathrm{psi} \mathrm{H}_{2}$ \\
\hline MoVanL-A ${ }^{b}$ & 2.85 & 0.96 & 1.44 & 0.47 & 0.13 & $50 \% \mathrm{CO} / \mathrm{H}_{2}$ \\
\hline MoVanL-B1c & 0.27 & ND & 0.60 & 0.17 & 0.05 & 1200 psi H2 \\
\hline MoVanL-B2c & 0.02 & ND & 0.14 & 0.05 & ND & $1200 \mathrm{psi} \mathrm{H}_{2}$ \\
\hline MoVanL-Cyc & 2.76 & 2.22 & 0.98 & 0.30 & 0.06 & $50 \% \mathrm{CO} / \mathrm{H}_{2}$ \\
\hline MoVanL-C2c & 0.08 & ND & 0.06 & 0.03 & ND & $1200 \mathrm{psi} \mathrm{H}_{2}$ \\
\hline
\end{tabular}

aGases reported in mmol/gram of feed.

bReaction conducted in $300-\mathrm{mL}$ reactor, $425^{\circ} \mathrm{C}, 1$ hour, 1000 psig cold.

'Reaction conducted in $1-\mathrm{L}$ reactor, $425^{\circ} \mathrm{C}, 30 \mathrm{~min} ., 1200$ psig cold.

conversion under syngas atmospheres only small amounts of methane, ethane, or propane were produced.

As seen for the gas analysis of the second-stage hydrotreating reactions, only minor amounts of light gases were produced, and thus most of the dealkylation appeared to have occurred in the first stage and the second stage involves upgrading under conditions that minimized severe cracking to light hydrocarbons. The conversion using the syngas atmosphere in the first stage showed no notable differences in the production of methane or higher hydrocarbons, again indicating no signification amounts of methanation or Fischer-Tropsch type chemistry. However, the extent of the carbon monoxide utilization was found to be much less than that found when the corresponding reaction was conducted in the $300-\mathrm{mL}$ reactor. We suspect the difference may be due to the higher pressures and gas/solid ratio in the 1-L reactor, and there may not be enough initial or autogenous water within the coal to allow for the water-gas-shift activity. Thus an optimization step in which additional water is added may be useful to enhance the yields for this conversion. Nevertheless, we found excellent conversions using this syngas atmosphere as described under Task 2. 


\section{TASK 2: LABORATORY-SCALE OPERATIONS}

The objectives of this task were to evaluate the effects of dispersed catalysts and atmospheres containing carbon monoxide for a two-stage liquefaction process. The following discussion describes our efforts for this project and how it may lead to a $\$ 25 / \mathrm{bbl}$ coal-to-liquids process when all improvements are integrated in a continuous multistage coal liquefaction plant configuration.

In Phase I, we examined general several concepts including dispersed catalysts, low rank coals, and syngas atmospheres. To evaluate our catalysts, we first used model coals (from the Argonne or Penn State coal banks) and pure paraffins as solvents. This process allowed us to better differentiate between the catalysts, without the interferences of solvent. The catalysts were then examined for the conversions of a Black Thunder subbituminous coal using a recycle vehicle derived from the same coal as the solvent. Following this testing, a representative first-stage conversion product was then upgraded, using a conventional hydrotreating catalyst in order to assess how the hydrotreated products from our methods compared with recent results in two-stage coal liquefaction development.

\section{CATALYSTS}

The MolyVanL was obtained from Wilsonville, the iron carbonyl and bis(cyclooctadiene) nickel $(0)$ referred to as $\left[\mathrm{Ni}(\mathrm{COD})_{2}\right]$, were purchased from Strem Corp. The thiolato iron carbonyl catalyst, $\left(\mu-\mathrm{S}_{2}\right) \mathrm{Fe}_{2}(\mathrm{CO})_{6}$, referred to as $\left[\mathrm{Fe}_{2} \mathrm{~S}_{2}(\mathrm{CO})_{6}\right]$, was prepared from iron carbonyl and sulfur by the method of Bogan et al. ${ }^{11}$ Ammonium tetrathiomolybdate $\left(\mathrm{NH}_{4}\right)_{2}\left(\mathrm{MoS}_{4}\right)$ was obtained from Alfa Chemicals and is referred to as $\mathrm{MoS}_{4}$. The organometallic molybdenum catalyst was $\left(\mathrm{C}_{5} \mathrm{H}_{5}\right)_{2} \mathrm{Mo}_{2}(\mu-\mathrm{SH})_{2}(\mu-\mathrm{S})_{2}$, referred to as $\mathrm{Mo}(\mathrm{OM})$, which was prepared by modifying the method of Cowens et al. ${ }^{12}$ The hydrotreating catalyst Shell 317, obtained courtesy of Criterion Chemical Company, was presulfided under flowing $10 \% \mathrm{H}_{2} \mathrm{~S} / \mathrm{H}_{2}$ before use.

\section{COAL CONVERSIONS IN SYNTHETIC SOLVENTS}

Before the work using the Black Thunder coal, we compared catalysts using model coals and synthetic nondonor solvents. For these types of conversions, we used the nonreactive solvent, $\mathrm{n}$-hexadecane, and a lignite from the Argonne coal bank. The advantage of conversions in this 
solvent is that we can distinguish between the effects of the solvent and the catalyst, since the recycle vehicle as used above and $\mathrm{H}$-donor solvents such as tetralin tend to obscure the effects of the catalyst. These model coal liquefaction experiments were conducted in $300-\mathrm{mL}$ Autoclave Engineers stirred reactor using $5.0 \mathrm{~g}$ of coal, $3 \mathrm{mmol}$ of catalyst, $30 \mathrm{~g}$ of solvent, and $500 \mathrm{psig}$ (cold) hydrogen. Reaction temperatures were held at $425^{\circ} \mathrm{C}$ for 20 minutes. The product was filtered through a medium porosity filter and separated into toluene-soluble (TS) and tolueneinsoluble (TI) fractions. The coal used was a Beulah-Zap seam North Dakota lignite from the Argonne Premium coal bank. ${ }^{13}$ Conversions are calculated from the amount of toluene-insoluble material and are on a carbon basis.

Table 4 compares model coal conversions using various catalysts for a hexadecane solvent system. The first three liquefaction experiments listed were conducted at $400^{\circ} \mathrm{C}$ and include a noncatalyzed conversion and conversions using molybdenum $\left[\mathrm{MoS}_{4}\right.$ and $\left.\mathrm{Mo}(\mathrm{OM})\right]$ catalysts on an Illinois \#6 coal. The fourth liquefaction experiment was conducted in tetralin for comparison. Most of the conversions are quite low, as expected with use of a very poor solvent. For instance, in the absence of catalyst, the Illinois \#6 coal was converted to $25 \%$ toluene soluble material. However, in the presence of the molybdenum catalysts, the conversions were greatly enhanced. The coal impregnated with $\mathrm{MoS}_{4}$ gave a conversion of $41 \%$ toluene-soluble material, and the organometallic molybdenum-impregnation [Mo(OM)] resulted in a conversion of 54\%, which is nearly as great as when tetralin was used as the conversion medium. Thus if the catalyst dispersion is great enough and does not require high temperature activation good yields can be obtained even in the absence of good liquefaction solvents. The practical import of this observation is that in an actual coal liquefaction process, where recycle will naturally provide at least a reasonably good solvent, catalyst use can be lowered.

The remaining five experiments, conducted at $425^{\circ} \mathrm{C}$ using an Argonne lignite coal, compare various soluble iron-, molybdenum-, and nickel-based catalysts. Both the soluble organometallic iron complexes $\left[\mathrm{Fe}(\mathrm{CO})_{5}\right.$ and $\left(\mathrm{FeS}_{2}(\mathrm{CO})_{2}\right]$ are effective for the low rank coals, giving conversions in the range of $40 \%$ (carbon based yields). In previous work we found that these catalysts gave only nominal conversions for the Illinois \#6 coal. X-ray analyses of the residues show that both catalysts were converted into pyrrhotite; however, the iron carbonyl also appeared to have been converted into elemental iron and other iron-based products. The Mo(OM) catalyzed reaction gave a higher conversion of $49 \%$ for this lignite, consistent with the better efficiency of Mo catalysts over Fe catalysts. 
Considering the organic chemistry of carboxylates, we also decided to investigate nickel as a potential catalyst for low rank coals. Whereas iron has a tendency to form dimers during

Table 4

\begin{tabular}{|c|c|c|c|}
\hline $\begin{array}{c}\text { CONVERSION TO } \\
\text { Catalyst } \\
\end{array}$ & $\begin{array}{c}\text { TOLUENE-SOLUBLE } \\
\text { Coal }\end{array}$ & $\begin{array}{l}\text { PRODUCTS IN } \\
T\left({ }^{\circ} \mathrm{C}\right)\end{array}$ & $\begin{array}{l}\text { HEXADECAN } \\
\% \mathrm{TS}^{\mathrm{b}} \\
\end{array}$ \\
\hline None & Illinois \# 6 & 400 & 25 \\
\hline $\mathrm{MoS}_{4}$ & Illinois \#6 & 400 & 41 \\
\hline Mo(OM) & Illinois \#6 & 400 & 54 \\
\hline$M o(O M)^{C}$ & Illinois \#6 & 400 & 61 \\
\hline None & Lignite & 425 & 24 \\
\hline $\mathrm{Fe}(\mathrm{CO})_{5}$ & Lignite & 425 & 41 \\
\hline $\mathrm{Fe}_{2} \mathrm{~S}_{2}$ & Lignite & 425 & 39 \\
\hline $\mathrm{Mo}(\mathrm{OM})$ & Lignite & 425 & 49 \\
\hline $\mathrm{Ni}(\mathrm{COD})_{2}$ & Lignite & 425 & 60 \\
\hline
\end{tabular}

\footnotetext{
aReaction conducted in a $300-\mathrm{mL}$ reactor with $5 \mathrm{~g}$ coal, $3 \mathrm{mmol}$ catalyst, $30 \mathrm{~g}$ solvent, and $500 \mathrm{psi}_{2}$ for $20 \mathrm{~min}$ at temperature.

byields calculated on daf basis for Illinois \#6 coal and on carbon basis for the lignite.

CReaction run in tetralin under identical conditions.
}

decarboxylation of organic acids, nickel tends to promote decarboxylation without dimerization and thus should be a better catalyst for oxygenated coals. Consistent with this premise, the conversion using a Ni-based catalyst [Ni(COD)2] shows that lignite conversion increased from $40 \%$ with the iron catalyst to $60 \%$ with the nickel catalyst.

Iron catalysts are well known to be effective for liquefaction of low rank coals. The iron may abstract oxygen via phenolics decomposition or catalyze decarboxylations. However, the iron-catalyzed decarboxylations as found in literature appear to promote dimerization to form ketones, most likely by a free radical route, and would most likely also cause retrogressive reactions and thus may have diminished yields. We expect molybdenum-based catalysts to be very effective, so it is not surprising that the molybdenum gives good conversions even in the absence 
of a good solvent. It is a good hydrogenation catalyst and most likely aids in hydrogenating the coal or, at least, in preventing dehydrogenation reactions, which cause retrogressive behavior.

From previous experiments we found that the $\mathrm{Mo}(\mathrm{OM})$ is more effective than other forms of molybdenum catalysts, including MolyVanL; thus we expected this catalyst to provide the highest conversion of the lignite. However, the nickel gave even higher conversions. Nickel is also a good hydrogenation catalysts, but it is known to promote clean decarboxylations with no dimerization. Thus it may provide additional properties for these low rank coals, which are high in carboxylates. In fact, as we show in the experiments using the Black Thunder and recycle solvent, the nickel catalyst was very effective in conversions to soluble products and in oil production.

Thus in the model system work we have shown that by use of highly dispersed catalysts, liquefaction yields in an inert solvent such as hexadecane can be nearly as great as in a moderately good H-donor solvent such as tetralin. Furthermore, the effectiveness of catalysts types may depend on coal type. As shown below, these results parallel those found on the Black Thunder/recycle vehicle conversions.

\section{BLACK THUNDER SCREENING STUDIES}

Screening studies were conducted for first-stage conversions using the Black Thunder recycle vehicle system. These screening studies involved several types of dispersed iron, molybdenum, and nickel catalysts under hydrogen and/or hydrogen/carbon monoxide atmospheres in a 300-mL batch reactor under nominal pressures of 1000 psia cold. The liquefaction products were fractionated into preasphaltenes (THF soluble), asphaltenes (toluene soluble), and oils (hexane soluble). The coal feed fraction was composed of 2.5 parts by weight of recycle vehicle and 1 part coal for a total of 70 grams of feed. For the iron catalysts, 2 wt $\%$ Fe in the feed was used, whereas for the $\mathrm{Ni}$ and Mo catalysts, $500 \mathrm{ppm}$ metal loading was used.

Two reactors were used for these experiments. Reactor A was used primarily to screen the iron and nickel catalysts and for selected molybdenum catalysts. Reactor B was used to screen the molybdenum catalysts. Reactor $B$ gave much poorer conversions than in Reactor $A$, due to differences in stirrer speed and configuration; therefore, selected catalysts were also tested in Reactor A for comparison.

The combination of low pressures of hydrogen and a low $\mathrm{H} / \mathrm{C}$ ratio recycle vehicle (1.055) generally gave very modest conversions. Nevertheless, such conditions should emphasize the better catalysts. Table 5 lists the results for the iron-based catalysts. For the conversions at 1000 
psi, the iron carbonyl catalysts (both iron carbonyl and thiolato iron carbonyl) gave the best conversions to soluble products, as seen by the THF-insoluble yields of $5.6 \%$ and $7.6 \%$, respectively. When the $\mathrm{Fe}(\mathrm{CO})_{5}$-catalyzed reaction was conducted at $850 \mathrm{psi} \mathrm{H}_{2}$, the conversion to THF-soluble products was considerably reduced, giving a $20.2 \%$ THF-insoluble product. However, when this lower partial pressure of hydrogen was supplemented with $\mathrm{CO}$ to provide a $20 \%$ CO content, ( $\mathrm{P}_{\text {tot }} 1000 \mathrm{psi}$ ) the conversions increased, giving only a $9.7 \%$ THF-insoluble yield, which is close to that achieved when pure hydrogen was used at $1000 \mathrm{psi}$. When the partial pressure of $\mathrm{CO}$ was increased to 50\%, conversions were still quite good (14.9 THF-insoluble product) and the final products exhibited increased oil yields. The thiolato iron carbonyl catalyst $\left[\mathrm{Fe}_{2} \mathrm{~S}_{2}(\mathrm{CO})_{6}\right]$ showed even better conversions in the presence of $\mathrm{CO}$. For instance, this catalyst exhibited a THF-insoluble product of only $10.7 \%$ for a $50 \% \mathrm{CO}$ atmosphere compared with $14.9 \%$ for the $\mathrm{Fe}(\mathrm{CO})_{5}$ catalyzed conversion, and for all reactions it gives both good conversions into THF-soluble material and good oil yields.

Table 6 lists the extent of the utilization of carbon monoxide for the various catalysts and the ratio of $\mathrm{CO}_{2}$ to $\mathrm{CO}$ content in the product gases. Note that the coal was previously dried before the conversion (with a $8 \%$ residual water content). The $\mathrm{CO}$ can be converted to $\mathrm{CO}_{2}$ by the conventional water-gas-shift reaction, or the $\mathrm{CO}$ could react with oxygen functionalities in the coal such as phenolics to produce $\mathrm{CO}_{2}$. As seen in Table 6 in the absence of coal and with $\mathrm{Fe}(\mathrm{CO})_{5}$ and added water, the majority of the $\mathrm{CO}$ is not converted. However, in the presence of coal and $\mathrm{Fe}(\mathrm{CO})_{5}$, the ratio was found to be 1.1. Efforts to increase it by adding water showed essentially no effect. The $\mathrm{Fe}_{2} \mathrm{~S}_{2}(\mathrm{CO})_{6}$-catalyzed reactions were shown to be more effective in utilization of the $\mathrm{CO}$, with a $3.3 \mathrm{CO}_{2}$-to- $\mathrm{CO}$ ratio, consistent with the increased conversions with this catalyst.

The molybdenum-catalyzed reactions were screened in a separate reactor that gives lower conversions for viscous feedstocks than the reactor used for the above experiments.* Nevertheless, we were able to determine the effects of catalyst type and carbon monoxide for various molybdenum catalysts, in particular, MolyVanL, which was recently used in Wilsonville, and a thiolato molybdenum complex [Mo(OM)], which we have used as a highly dispersed catalyst that already in its most active form. As seen in Table 7, the Mo(OM)-catalyzed conversion gave much better conversions to THF-soluble material as well as excellent oil yields. When a 50\% $\mathrm{CO} / \mathrm{H}_{2}$ mixture was used instead of pure hydrogen the MolyVanL catalyst, essentially the same

\footnotetext{
* The poorer conversions observed with Reactor B apparently occurred because the stirrers were modified differently in the two reactors to facilitate stirring of reactor charges that are much less than the 300 -mL capacity. The differences are most pronounced when the reaction mixture is viscous, as it is with the high resid-content Black Thunder Vehicle.
} 
Table 5

DAF YIELDS OF FRACTIONATED PRODUCTS ${ }^{a}$ USING IRON CATALYSTS Reactor A

\begin{tabular}{|c|c|c|c|c|c|}
\hline Catalyst & Atmosphere ${ }^{b}$ & $\begin{array}{l}\text { THF } \\
\text { Insol } \\
\end{array}$ & Preasphaltene & Asphaltene & Olls \\
\hline Recycle & $1000 \mathrm{psi} \mathrm{H}_{2}$ & 6.7 & 4.4 & 51.3 & 29.7 \\
\hline $\mathrm{Fe}_{2} \mathrm{O}_{3}$ & $1000 \mathrm{psi} \mathrm{H}_{2}$ & 11.8 & 12.7 & 36.1 & 18.3 \\
\hline $\mathrm{Fe}_{2} \mathrm{O}_{3} \cdot \mathrm{SO}_{4}$ & 1000 psi $\mathrm{H}_{2}$ & 12.1 & 11.2 & 40.1 & 17.2 \\
\hline $\mathrm{Fe}(\mathrm{CO})_{5}$ & $850 \mathrm{psi}_{2}$ & 20.2 & 6.5 & 29.8 & 14.1 \\
\hline $\mathrm{Fe}(\mathrm{CO})_{5}$ & $1000 \mathrm{psi} \mathrm{H}_{2}$ & 5.6 & 7.3 & 53.4 & 21.2 \\
\hline $\mathrm{Fe}(\mathrm{CO})_{5}$ & $20 \% \mathrm{CO} / \mathrm{H}_{2} \mathrm{c}$ & 9.7 & 4.8 & 39.0 & 20.9 \\
\hline $\mathrm{Fe}(\mathrm{CO})_{5} / \mathrm{H}_{2} \mathrm{O}$ & $20 \% \mathrm{CO} / \mathrm{H}_{2} \mathrm{c}$ & 13.8 & 11.5 & 53.4 & 4.5 \\
\hline $\mathrm{Fe}(\mathrm{CO})_{5}$ & $50 \% \mathrm{CO} / \mathrm{H}_{2} \mathrm{c}$ & 14.9 & 18.7 & 35.8 & 26.1 \\
\hline $\mathrm{Fe}(\mathrm{CO})_{5} / \mathrm{H}_{2} \mathrm{O}$ & $50 \% \mathrm{CO} / \mathrm{H}_{2} \mathrm{c}$ & 13.9 & 14.0 & 46.3 & 7.2 \\
\hline $\mathrm{Fe}_{2} \mathrm{~S}_{2}(\mathrm{CO})_{6}$ & $1000 \mathrm{psi} \mathrm{H}_{2}$ & 7.6 & 11.8 & 37.5 & 24.4 \\
\hline $\mathrm{Fe}_{2} \mathrm{~S}_{2}(\mathrm{CO})_{6}$ & $50 \% \mathrm{CO}^{c}$ & 10.7 & 11.2 & 35.4 & 23.9 \\
\hline
\end{tabular}

Table 6

EFFECT OF CATALYST ON CO UTILIZATIONa

\begin{tabular}{lc}
\multicolumn{1}{c}{ Catalyst/Conditions } & $\mathrm{CO}_{2} / \mathrm{CO}$ Ratio \\
\hline $\mathrm{Fe}(\mathrm{CO})_{5} / \mathrm{Recycle} / \mathrm{H}_{2} \mathrm{O}$ & 0.25 \\
$\mathrm{Fe}(\mathrm{CO})_{5}$ & 1.1 \\
$\mathrm{Fe}(\mathrm{CO})_{5} / \mathrm{H} 2 \mathrm{O}$ & 1.3 \\
$\mathrm{Fe}_{2} \mathrm{~S}_{2}(\mathrm{CO})_{6}$ & 3.3 \\
$\mathrm{MolyVanL}$ & 3.0 \\
$\mathrm{Ni}(\mathrm{COD})_{2}$ & 5.0 \\
\hline
\end{tabular}

a Reactions run with $50 \% \mathrm{CO}$. 
yields of THF-soluble and oil fractions were found. Furthermore, as shown in Table 6, the utilization of $\mathrm{CO}$ was much more effective for the molybdenum-based catalyst than for the iron carbonyl catalyst and about the same as for the iron thiolato catalyst. The molybdenum thiolato catalyst was not heated under syngas atmospheres, but we expect it would also be very effective.

Prompted by the high conversions obtained for the $\mathrm{Ni}(\mathrm{COD})_{2}$-catalyzed lignite conversions, we also conducted conversions on Black Thunder coal with this catalyst, both under a hydrogen atmosphere and under a syngas atmosphere containing $50 \% \mathrm{CO}$. Table 8 compares the best iron-catalyzed conversions and the results from these Ni-catalyzed reactions. Table 8 also contains the results from selected molybdenum [MolyVanL and the combination MolyVanL/Fe(CO)s] catalyzed conversions that were conducted in reactor $\mathrm{A}$, the same reactor in which the iron- and nickel-catalyzed conversions were conducted. The last column of this table also contains coal conversions based on THF-soluble materials and accounts, on the basis of experiments with no coal, for contributions of THF-soluble material from the recycle solvent. The nickel-catalyzed reactions both under hydrogen and under $50 \%$ carbon monoxide gave very high conversions to THF-soluble material, with overall coal conversions in excess of $90 \%$. Given the presence of $\mathrm{H}_{2} \mathrm{~S}$ in the conversion atmosphere, we believe (based on thermodynamic calculations) that there should be no problem with carbonyls of nickel. As shown in Table 6, the nickel also gives the most $\mathrm{CO}$ utilization, with a $\mathrm{CO}_{2}$-to- $\mathrm{CO}$ ratio of 5.0.

Of all the conversions shown in Table 8, the molybdenum based reactions showed the highest conversions, with coal conversions in excess of $95 \%$, and also had the highest oil yields; in particular, the reaction with MolyVanL and iron carbonyl had an oil yield of over 30\%. However, according to the data obtained from reactor B, and the model coal results, we expected that the use of the $\mathrm{Mo}(\mathrm{OM})$ catalyst would further enhance the yields and provide a higher quality product. In addition, the use of nickel-based catalysts, either as dispersed nickel or as nickel promoters appears to be promising and should allow better use of syngas atmospheres, which would greatly enhance the economics of coal liquefaction. Thus, the use of $\mathrm{CO}$ in the coal liquefaction process appears to be feasible without the addition of excess water, so the problems associated with excess water such as emulsions, corrosion, and high pressures can be minimized.

\section{TWO-STAGE LIQUEFACTION EXPERIMENTS}

Having screened various catalysts and reaction conditions in single-stage batch reactors we conducted a simulated two-stage liquefaction conversion to estimate the economics under actual processes conditions. For this simulated conversion, we used the MolyVanL catalyst in hydrogen 
Table 7

DAF YIELDS USING MOLYBDENUM CATALYSTSa

Reactor B

\begin{tabular}{llcccc}
\multicolumn{1}{c}{ Catalyst } & Atmosphere & $\begin{array}{c}\text { THF } \\
\text { Insol }\end{array}$ & Preasphaltene & Asphaltene & Oils \\
\hline MolyVanL & $1000 \mathrm{psi} \mathrm{H}_{2}$ & 20.6 & 8.8 & 32.3 & 20.2 \\
MolyVanL & $50 \% \mathrm{CO}$ & 18.4 & 10.0 & 27.7 & 22.1 \\
Mo(OM) & $1000 \mathrm{psi} \mathrm{H}_{2}$ & 10.9 & 12.4 & 32.6 & 23.2 \\
\hline
\end{tabular}

apeaction conducted in a $300-\mathrm{mL}$ reactor with $20 \mathrm{~g}$ Black Thunder Wyodak coal, $500 \mathrm{ppm}$ metal in catalyst, $50 \mathrm{~g}$ Recycle solvent, at $425^{\circ} \mathrm{C}$ for $1 \mathrm{hr}$.

bAtmosphere contained $3 \% \mathrm{H}_{2} \mathrm{~S}$ in either $\mathrm{H}_{2}$ or $\mathrm{CO} / \mathrm{H}_{2}$.

Table 8

DAF YIELDS OF USING VARIOUS METAL CATALYSTSa

Reactor A

\begin{tabular}{|c|c|c|c|c|c|c|}
\hline Catalyst & Atmosphere & $\begin{array}{l}\text { THF } \\
\text { Insol }\end{array}$ & Preasphaltene & Asphaltene & Oils & $\begin{array}{c}\% \\
\text { Convb }\end{array}$ \\
\hline Recycle & As received & 8.7 & 7.5 & 60.9 & 23.2 & - \\
\hline Recycle & $1000 \mathrm{psi} \mathrm{H}_{2}$ & 6.7 & 4.4 & 51.3 & 29.7 & - \\
\hline $\mathrm{Fe}(\mathrm{CO})_{5}$ & $1000 \mathrm{psi} \mathrm{H}_{2}$ & 5.8 & 7.5 & 54.9 & 21.7 & 96.5 \\
\hline $\mathrm{Fe}(\mathrm{CO})_{5}$ & $50 \% \mathrm{CO}$ & 14.9 & 18.7 & 34.8 & 25.4 & 64.7 \\
\hline $\mathrm{Fe}_{2} \mathrm{~S}_{2}(\mathrm{CO})_{6}$ & $1000 \mathrm{psiH}_{2}$ & 7.6 & 11.8 & 37.5 & 24.4 & 90.2 \\
\hline $\mathrm{Fe}_{2} \mathrm{~S}_{2}(\mathrm{CO})_{6}$ & $50 \% \mathrm{CO}$ & 10.7 & 11.2 & 35.4 & 23.9 & 79.4 \\
\hline MolyVanLC & $1000 \mathrm{psi} \mathrm{H}_{2}$ & 5.1 & 10.0 & 40.2 & 28.8 & 98.9 \\
\hline MolyVanLc $+F e$ & 1000 psi H2 & 5.8 & 7.6 & 37.0 & 31.2 & 96.5 \\
\hline $\mathrm{Ni}(\mathrm{COD})_{2}{ }^{\mathrm{c}}$ & 1000 psi H2 & 7.2 & 11.6 & 41.8 & 20.7 & 91.6 \\
\hline $\mathrm{Ni}(\mathrm{COD})_{2}{ }^{\mathrm{C}}$ & $50 \% \mathrm{CO}$ & 7.4 & 11.8 & 46.3 & 23.3 & 90.9 \\
\hline
\end{tabular}

aReaction conducted in a $300-\mathrm{mL}$ reactor with $20 \mathrm{~g}$ Black Thunder Wyodak coal, $2 \%$ iron metal in catalyst, $50 \mathrm{~g}$ Recycle solvent, at $425^{\circ} \mathrm{C}$ for $1 \mathrm{hr}$. Atmosphere contained $3 \% \mathrm{H}_{2} \mathrm{~S}$ in $\mathrm{H}_{2}$.

bCoal conversion $=100-[($ THF Insol -4.8$) / 28.6] \times 100$.

c500 ppm metal added. 
atmospheres and, for comparison, in syngas atmospheres. Although we have identified more active catalysts in both hydrogen and syngas atmospheres, we decided to use this catalyst as a baseline case. The second-stage conversion in each case used a hydrogen atmosphere and a commercial shell 317 NiMo catalyst.

In our catalyst screening work, the products obtained from the 300 -mL autoclave were fractionated and separated into various classes by solvent solubilities, but here we used a distillation scheme for the larger scale conversions obtained from the 1- $\mathrm{L}$ autoclave. The reason for this difference in analysis is due to difference in properties of these products after addition of the hydrotreating catalyst, making them a much more soluble and distallable product. We used a distillation method based on ASTM method D 1160-87. Four boiling point fractions up to $1000^{\circ} \mathrm{F}$ and residues were collected (see Table 10). This type of analysis allows us to make better comparisons with existing data for coal liquefaction.

The feedstock for the simulated two-stage conversion of the Black Thunder Coal consisted of 2.5 parts by weight of recycle vehicle from Wilsonville run \#263 (150g) to 1 part Black Thunder coal (60 g) in an Autoclave Engineers 1-L stirred reactor. MolyVanL (500 ppm Mo) was added as the first-stage catalyst, and sulfided Shell 317 NiMo catalyst (6.3\% of the feed), was added as the second-stage catalyst. The total gas content was 1200 psi (cold charge) containing $97 \% \mathrm{H}_{2}$ and $3 \% \mathrm{H}_{2} \mathrm{~S}$. The first-stage conversion was conducted for 30 minutes at $425^{\circ} \mathrm{C}$, and the second-stage conversion at $400^{\circ} \mathrm{C}$ for 30 minutes. During this conversion, we also tested the use of a syringe pump integrated into the autoclave so that the hydrotreating catalyst could be injected in situ as a slurry, simulating close coupling to the second stage reactor. (For this prototype demonstration, we used toluene as a slurry medium rather than the recycle vehicle; all analyses were corrected for the added toluene.) Only a part of the catalyst loading was added, so the reactor was cooled and the additional amount of NiMo catalyst was added, for a total of $6.3 \%$ supported NiMo of the coal/slurry feed. Fresh hydrogen $/ \mathrm{H}_{2} \mathrm{~S}$ was added, and the upgrading step was continued at $400^{\circ} \mathrm{C}$. The reason for the low injection amount from the syringe pump was an error in design of the pump head, leading to a large dead volume. The pump head is being redesigned to reduce this dead volume.

Tables 10 and 11 lists the distillation yields and elemental analyses for the hydrogen atmosphere and syngas atmosphere conversions, respectively. For comparison, the distillation fractions yields of the recycle vehicle itself are shown in Table 9. For the hydrogen atmosphere conversion, the hydrotreating catalyst was injected in situ in as a toluene slurry. The amount of toluene was determined by GC analysis, and the yields were corrected accordingly. However, an 
Table 9

\section{ANALYSES OF RECYCLE VEHICLE DISTILLATION FRACTIONS}

\begin{tabular}{lllllll}
$\begin{array}{c}\text { Recycle Vehicle } \\
\text { Fraction }\end{array}$ & Wt $\%$ & C & H & N & S & H/C \\
\hline $482-850$ & 18.22 & 87.78 & 9.95 & 0.55 & & 1.350 \\
$850-1000$ & 31.78 & 88.23 & 9.24 & 0.50 & & 1.247 \\
$1000+$ & 40.65 & $88.38^{a}$ & $6.85^{\mathrm{a}}$ & $0.79^{\mathrm{a}}$ & & 0.923 \\
Ash & 9.35 & & & & \\
\hline
\end{tabular}

a. Corrected on an ash-free basis.

Table 10

ANALYSES OF DISTILLATION PRODUCTS FOR $\mathrm{H}_{2} / \mathrm{H}_{2}$ CONVERSIONa

\begin{tabular}{lcccccc}
\multicolumn{1}{c}{ Fraction ${ }^{\circ} \mathrm{F}$} & Wt $\%$ & $\mathrm{C}$ & $\mathrm{H}$ & $\mathrm{N}$ & $\mathrm{S}$ & $\mathrm{H} / \mathrm{C}$ \\
\hline $\mathrm{C} 5-350$ & 4.3 & $83.63^{\mathrm{b}}$ & $16.37^{\mathrm{b}}$ & - & - & $2.332^{\mathrm{b}}$ \\
$350-650$ & 21.6 & 86.24 & 10.13 & 0.68 & 0.17 & 1.398 \\
$650-850$ & 14.9 & 87.91 & 9.91 & 0.64 & 0.30 & 1.344 \\
$850-1000$ & 15.9 & 88.48 & 9.02 & 0.70 & 0.49 & 1.215 \\
$1000+$ & 25.0 & $89.60^{\mathrm{c}}$ & $6.12^{\mathrm{c}}$ & $0.97^{\mathrm{c}}$ & - & 0.812 \\
$\mathrm{Ash}$ & 8.5 & & & & & \\
$\mathrm{H} \mathrm{O}$ & 5.5 & & & & & \\
\hline
\end{tabular}

afirst stage $425^{\circ} \mathrm{C}, 30 \mathrm{~min}$., second stage $400^{\circ} \mathrm{C}, 30 \mathrm{~min}$. Pressure $1200 \mathrm{psig}$ cold.

bEstimated analysis after subtracting added toluene and assuming aliphatic hydrocarbon product having an $\mathrm{H} / \mathrm{C}$ ratio appropriate for this boiling range.

c Corrected on an ash-free basis. 
Table 11

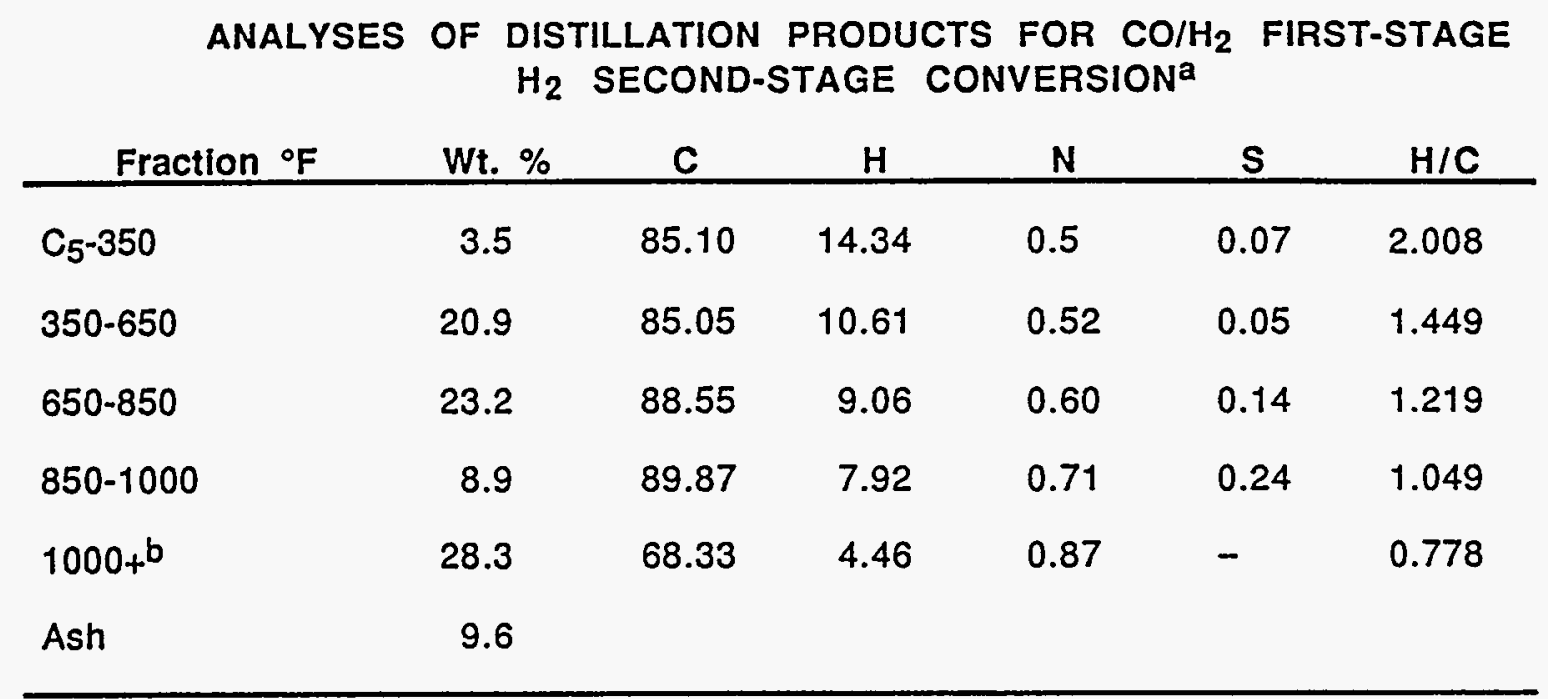

afirst stage $425^{\circ} \mathrm{C}, 30 \mathrm{~min}$., second stage $400^{\circ} \mathrm{C}, 30 \mathrm{~min}$. Pressure 1200 psig cold.

${ }^{b}$ Corrected on an ash free basis.

accurate elemental analysis for the $\mathrm{C}_{5}$ to $350^{\circ} \mathrm{F}$ fraction could not be obtained and was assumed to be similar to that of a saturated hydrocarbon for use in the economic analysis.

The conversions using the two systems were quite similar, with the syngas conversion giving slightly lighter product, $\left(\mathrm{C}_{5}-850^{\circ} \mathrm{F}\right.$ product contents were $\left.47.6 \%\right)$ than the hydrogen conversion products $\left(\mathrm{C}_{5}-850^{\circ} \mathrm{F}\right.$ product contents were $\left.40.8 \%\right)$. Furthermore, the residues $(1000+)$ after liquefaction were quite similar, at $25 \%$ for the hydrogen conversion and $28 \%$ for the syngas conversion.

These results are very encouraging, and from our other screening work, we have found even more effective catalysts for coal conversions and for syngas utilization for the first stage in the coal liquefaction. For instance, we have found that of the molybdenum-based catalysts, a thiolato molybdenum was the most effective. We also found that with proper catalyst, high coal conversions could be achieved using syngas atmospheres in the absence of added water or base. The effectiveness of carbon monoxide utilization was in the order of $\mathrm{Ni}>\mathrm{Mo}>\mathrm{Fe}$ based catalysts. Also, of the iron-based catalysts, a thiolato iron was more effective than carbonyl iron or iron oxide in carbon monoxide utilization. Thus we believe that with proper catalyst and process development, these methods may significantly improve the final product quality and economics during coal liquefaction. 


\section{TASK 3: TECHNICAL AND ECONOMIC ASSESSMENT}

\section{COMMERCIAL LIQUEFACTION PLANT DESCRIPTION}

Bechtel Corp. has developed a preliminary conceptual design for a commercial-size, integrated coal liquefaction plant based on the results from SRI laboratory-scale experiments. These experiments were utilized the commercially produced catalyst, MolyVanL. However, as previously noted SRI has identified other catalysts with significantly higher activities. This section describes the overall configuration of the integrated facility and its design basis; it also summarizes the major performance and design features of the plant.

\section{Plant Summary}

The conceptual plant is envisioned as a grassroots facility located near the coal mine mouth and is designed to produce at full capacity about 65,000 barrels per day of liquid products, consisting of liquid propane, crude naphtha, and crude gas oil, from about 35,570 tons per day of Black Thunder subbituminous coal feedstock. In addition to coal, the plant imports raw water for process and utility use and a relatively small amount of natural gas for on-site power generation. The plant is designed to consume all the fuel gases produced in the plant by using them for process heating and for generating steam and power for the plant. In addition to the main liquid products, the plant also produces 135 tons per day of anhydrous ammonia and 104 tons per day of elemental sulfur as by-product.

The plant uses a directly coupled, two-stage liquefaction process concept. The first reaction stage uses a slurry flow reactor and soluble dispersed catalyst, and the second reaction stage uses an ebullated-bed, supported-catalyst reactor with constant catalyst addition and removal. Process-derived solvent is used to slurry the coal. The hydrogen required for the reaction is produced by coal gasification.

\section{Design Basis}

A preliminary conceptual design was developed for a grassroots Nth plant, which is defined as the Nth commercial plant built when the technology, plant design, and operation are well established. Compared with the first commercial plant, the Nth plant design characteristically 
minimizes overcapacity and sparing, requires the shortest project schedule to construct and start, and incurs the lowest reasonable engineering cost.

Table 12 summarizes the major design criteria and considerations used to develop the preliminary conceptual design for the plant. The liquefaction reaction conditions and yields were based on the results from one of SRI laboratory-scale batch experiments. The raw SRI data were normalized and slightly adjusted, as appropriate, to simulate a continuous, steady-state coal liquefaction operation with solvent and gas recycles.

\section{Process Description}

Figure 1 diagrams the process configuration for the overall integrated coal liquefaction plant, and Table 13 summarizes the flow rates and compositions of the major process streams shown on the flow diagram. Table 14 summarizes the various products, by-products, raw materials, and resources used in the plant. As Table 14 shows, the naphtha and gas oil are crude products containing relatively high levels of sulfur and nitrogen. Hydrotreating of these products was not considered in the conceptual design because of the lack of more complete characterization of these products (as reported by SRI) and because of the lack of suitable data (on comparable products) that can be used to obtain a reasonable estimate of the performance, operating requirements, and system sizing required for hydrotreating these products.

As shown in Figure 1, the coal feedstock (run-of-mine coal) received at the plant site is first screened and a portion of the screened coal is sent directly to the gasification system. The rest of the screened coal is then crushed, ground, and dried using hot nitrogen to produce coal with the required particle size and moisture content.

The dried coal is mixed with recycled solvent produced in the downstream units and fresh MolyVan soluble catalyst to form a slurry feed to the liquefaction reactors. The recycle solvent consists of an oil stream obtained from the distillation towers in the primary separation and fractionation unit and an extract product obtained from solid/liquid separation unit. The coal slurry is heated, combined with preheated make-up and recycle hydrogen, and then fed to the first-stage reactor. Temperature is controlled in the reactor by introducing a portion of the total gas with coal slurry at the inlet, while the remainder of the gas is fed as quench at two points along the flow path. The reactor effluent is cooled indirectly with fresh and recycle hydrogen, and the vapor is separated from the liquid. The vapor joins the second-stage reactor effluent vapor, while the liquid is combined with hydrogen and fed to the second-stage ebullated-bed reactor. 
Table 12

\section{MAJOR DESIGN CRITERIA AND CONSIDERATIONS}

\section{Feed Coal}

Source

Moisture content (as received)

Moisture content (after drying)

Particle size for liquefaction

Analysis

Liquefaction First Stage

Type

Catalyst

Coal/dispersed catalyst ratio

Solvent/coal ratio

Recycle solvent, wt\% $350-850^{\circ} \mathrm{F}$

$850-1000^{\circ} \mathrm{F}$

$1000^{\circ} \mathrm{F}$

Ash

Nominal reactor temperature

Nominal reactor pressure

Reactor space velocity

Liquefaction Second Stage

Type

Catalyst

Coal/catalyst ratio

Catalyst replacement rate

Nominal reactor temperature

Nominal reactor pressure

Reactor space velocity

Total hydrogen feed-to-coal ratio

Total hydrogen consumption (uptake)

Liquid product yield

$\mathrm{C}_{5}-350^{\circ} \mathrm{F}$

$350-650^{\circ} \mathrm{F}$

$650-850^{\circ} \mathrm{F}$

$850-1000^{\circ} \mathrm{F}$

$1000^{\circ} \mathrm{F}+$

Air separation oxygen product

Gas turbine inlet fuel gas pressure

Raw coal storage

Propane and by-products storage

Liquid products storage

Plant operating factor
Black Thunder

21.21 wt\%

$8.0 w t \%$

$50 \%$ less than 200 mesh

(see Table)

Slurry, Co-current

MolyVan L (dispersed)

$46.1 \mathrm{lb} / \mathrm{lb}$

$2.32 \mathrm{lb} / \mathrm{lb}$

18.2

31.8

40.7

9.3

$797^{\circ} \mathrm{F}\left(400^{\circ} \mathrm{C}\right)$

1700 psia

$46 \mathrm{lb}$ coal $(\mathrm{mf}) / \mathrm{hr} / \mathrm{t}^{3}$ reactor

Ebullated bed

Shell (Criterion) $317 \mathrm{NiMo}$ on alumina

$0.56 \mathrm{coal}$ (maf)/lb catalyst

$3 \mathrm{lb}$ catalyst/ton (mf) coal

$797^{\circ} \mathrm{F}\left(400^{\circ} \mathrm{C}\right)$

1700 psia

$102 \mathrm{lb}$ coal (mf)/hr/cu-ft reactor

$0.174 \mathrm{lb} / \mathrm{b}$ coal feed

7.93 w\% maf coal

wt\% maf coal

17.82

28.65

16.66

3.3

5.13

99.5 vol\% pure oxygen

400 psig

28 days

15 days

30 days

$88.4 \%$ 


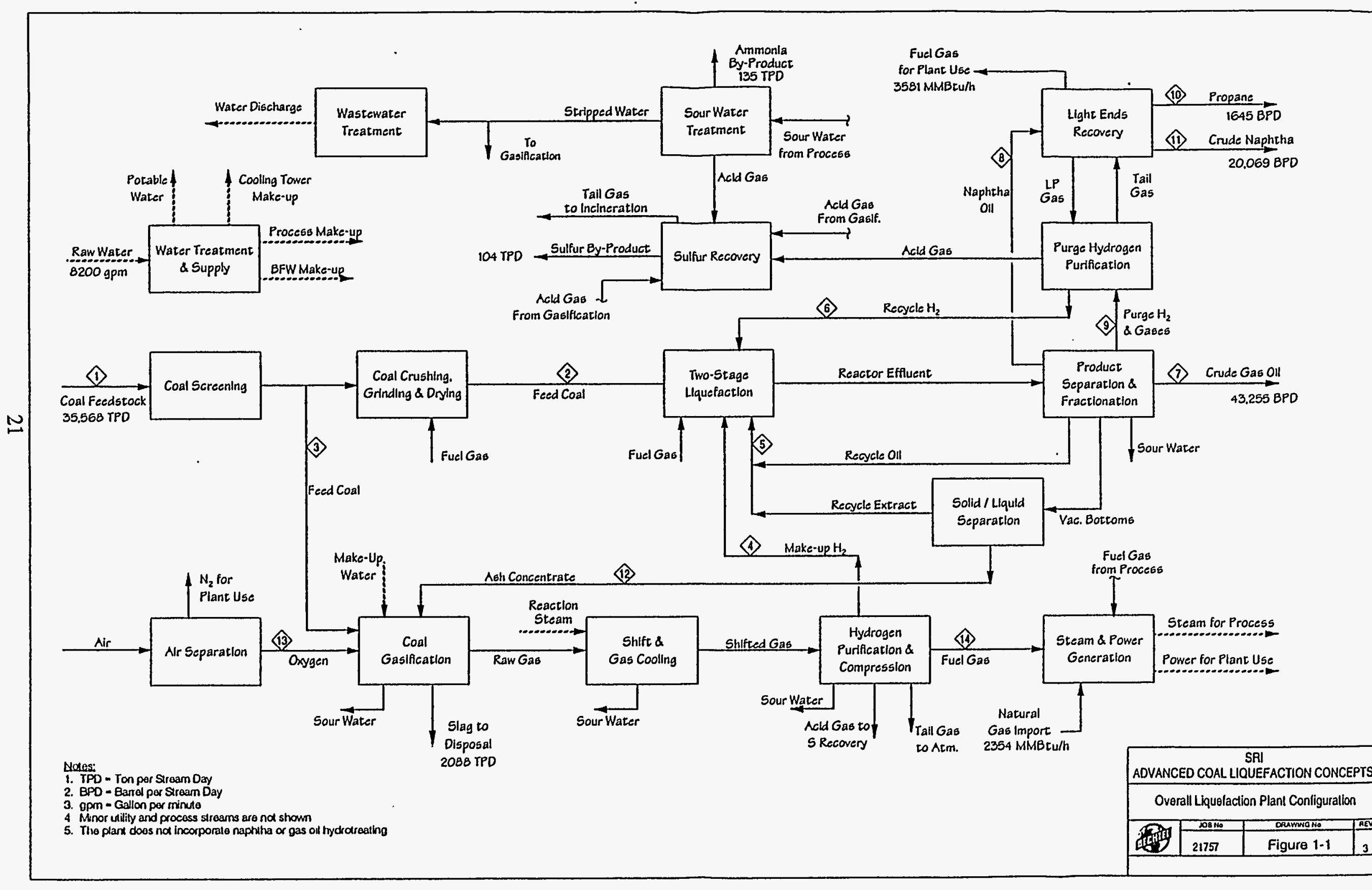

Figure 1. Overall liquelaction plant configuration. 
Table 13

MAJOR PROCESS STREAMS SUMMARY

\begin{tabular}{|c|c|c|c|c|c|c|c|}
\hline & \multicolumn{7}{|c|}{ Stream Number } \\
\hline & $\langle 1\rangle$ & $<2\rangle$ & $\langle 3\rangle$ & $<4>$ & $<5>$ & $<6>$ & $<7\rangle$ \\
\hline $\begin{array}{c}\text { Component } \\
\text { (lb/hr) }\end{array}$ & $\begin{array}{c}\text { Feedstock } \\
\text { Coal }\end{array}$ & $\begin{array}{l}\text { Liquef. } \\
\text { Feed Coal }\end{array}$ & $\begin{array}{c}\text { Gasif. } \\
\text { Feed Coal }\end{array}$ & $\begin{array}{l}\text { Make-up } \\
\text { Hydrogen }\end{array}$ & $\begin{array}{l}\text { Recycle } \\
\text { Solvent }\end{array}$ & $\begin{array}{c}\text { Recycle } \\
\text { Hydrogen }\end{array}$ & $\begin{array}{l}\text { Crude } \\
\text { Gas Oil } \\
\end{array}$ \\
\hline $\mathrm{H}_{2}$ & & & & 113,493 & & 169,628 & \\
\hline $\mathrm{CO}$ & & & & & & & \\
\hline $\mathrm{CO}_{2}$ & & & & & & & \\
\hline $\mathrm{CH}_{4}$ & & & & & & 50,888 & \\
\hline $\mathrm{C}_{2} \mathrm{H}_{6}$ & & & & & & 25,444 & \\
\hline $\mathrm{C}_{3} \mathrm{H}_{8}$ & & & & & & 16,963 & \\
\hline $\mathrm{NH}_{3}$ & & & & & & & \\
\hline $\mathrm{H}_{2} \mathrm{~S}$ & & & & 99 & & 516 & \\
\hline $\mathrm{H}_{2} \mathrm{O}$ & 628,667 & 130,435 & 224,872 & & & 3,393 & \\
\hline $\mathrm{N}_{2}$ & & & & 15,889 & & 2,544 & \\
\hline $\mathrm{O}_{2}$ & & & & & & & \\
\hline $\mathrm{C}_{5-350^{\circ} \mathrm{F}}$ & & & & & & 1,696 & 6,181 \\
\hline $350-650^{\circ} \mathrm{F}$ & & & & & 845,218 & & 395,597 \\
\hline $650-850^{\circ} \mathrm{F}$ & & & & & 625,317 & & 228,969 \\
\hline $850-1000^{\circ} \mathrm{F}$ & & & & & 870,676 & & \\
\hline $1000^{\circ} \mathrm{F}+$ & & & & & $1,354,385$ & & \\
\hline Coal (maf) & $2,161,356$ & $1,388,247$ & 773,109 & & & & \\
\hline Ash & 173,987 & 111,753 & 62,235 & & 89,674 & & \\
\hline Total & $2,964,010$ & $1,630,435$ & $1,060,215$ & 129,481 & $3,785,269$ & 271,072 & 630,747 \\
\hline
\end{tabular}


Table 13 (Concluded)

\begin{tabular}{|c|c|c|c|c|c|c|c|}
\hline & \multicolumn{7}{|c|}{ Steam Number } \\
\hline & $<8>$ & $<9>$ & $\langle 10\rangle$ & $\langle 11\rangle$ & $<12>$ & $\langle 13\rangle$ & $\langle 14\rangle$ \\
\hline $\begin{array}{c}\text { Component } \\
\text { (lb/hr) }\end{array}$ & $\begin{array}{c}\text { Naphtha } \\
\text { Oil }\end{array}$ & $\begin{array}{c}\text { Purge } \mathrm{H}_{2} \\
\text { \& Gases }\end{array}$ & $\begin{array}{l}\text { Propane } \\
\text { Product } \\
\end{array}$ & $\begin{array}{c}\text { Crude } \\
\text { Naphtha } \\
\end{array}$ & $\begin{array}{l}\text { Ash } \\
\text { Conc. }\end{array}$ & Oxygen & $\begin{array}{l}\text { Fuel } \\
\text { Gas }\end{array}$ \\
\hline $\mathrm{H}_{2}$ & & 173,089 & & & & & 8,383 \\
\hline co & & & & & & & 27,488 \\
\hline $\mathrm{CO}_{2}$ & & 99,968 & & & & & 12,043 \\
\hline $\mathrm{CH}_{4}$ & & 145,014 & & & & & 155 \\
\hline $\mathrm{C}_{2} \mathrm{H}_{6}$ & 1,287 & 74,426 & 167 & & & & \\
\hline $\mathrm{C}_{3} \mathrm{H}_{8}$ & 784 & 28,244 & 12,004 & & & & \\
\hline $\mathrm{NH}_{3}$ & 25 & 126 & & & & & \\
\hline $\mathrm{H}_{2} \mathrm{~S}$ & 43 & 4,765 & & & & & \\
\hline $\mathrm{H}_{2} \mathrm{O}$ & & 11,908 & & & & & \\
\hline $\mathrm{N}_{2}$ & & 18,433 & & & & 6,371 & 17,478 \\
\hline $\mathrm{O}_{2}$ & & & & & & $1,026,898$ & \\
\hline $\mathrm{C}_{5}-350^{\circ} \mathrm{F}$ & 180,045 & 62,865 & & 241,214 & & & \\
\hline $350-650^{\circ} \mathrm{F}$ & 1,691 & 461 & & 1,747 & & & \\
\hline $650-850^{\circ} \mathrm{F}$ & & & & & & & \\
\hline $850-1000^{\circ} \mathrm{F}$ & & & & & 45,825 & & \\
\hline $1000^{\circ} \mathrm{F}+$ & & & & & 71,283 & & \\
\hline Coal (maf) & & & & & & & \\
\hline Ash & & & & & 111,753 & & \\
\hline Total & 183,876 & 619,300 & 12,171 & 242,961 & 228,861 & $1,033,269$ & 65,547 \\
\hline
\end{tabular}


Table 14

PRODUCTS AND RESOURCES

\section{Products}

Liquid Propane

Flow rate

Ethane

Propane

$1,645 \mathrm{bbl} / \mathrm{day}$

2 vol\%

98 vol\%

Naphtha

$\begin{array}{lll}\text { Flow rate } & 20,069 & \text { bbl/day } \\ \text { C5 }_{5}-350^{\circ} \mathrm{F} & 98 & \text { vol\% } \\ 350-650^{\circ} \mathrm{F} & 2 & \text { vol\% } \\ \text { API Gravity } & 39 & \\ \text { N content, wt\% } & <0.5 & \\ \text { S content, wt\% } & <0.15 & \end{array}$

Gas oil

$\begin{array}{lll}\text { Flow rate } & 43,255 & \text { bbl/day } \\ {\text { C } 5-350^{\circ} \mathrm{F}} & 1.2 & \text { vol\% } \\ 350-650^{\circ} \mathrm{F} & 63.9 & \text { vol\% } \\ 650-850^{\circ} \mathrm{F} & 34.9 & \text { vol\% } \\ \text { API gravity } & 9.7 & \\ \text { N content, wt\% } & 0.66 \% & \\ \text { S content, wt } \% & <0.16 & \end{array}$

Sulfur by-product $\quad 104.4 \quad$ ton/day

Ammonia by-product 135 ton/day

Resource Requirements

$\begin{array}{cll}\begin{array}{c}\text { Coal feedstock } \\ \text { Catalyst }\end{array} & \begin{array}{l}35,568 \\ 28,028\end{array} & \begin{array}{l}\text { ton/day (as received) } \\ \text { ton/day (mf) }\end{array} \\ \begin{array}{c}\text { First Stage } \\ \text { (MolyVanL) }\end{array} & 315 & \text { ton/day } \\ \begin{array}{c}\text { Second Stage } \\ \text { (Shell criterion) }\end{array} & 325 & \text { ton/day } \\ \text { Natural gas import } & 2,354 & \begin{array}{l}\text { MMBtu/hr } \\ \text { MMsct/day }\end{array} \\ & 58 & \text { gpm }\end{array}$


In the Primary Separation unit, the effluent from the second-stage reactor is flashed at two low pressure levels and cooled to separate the vapor from the liquid. An amount of wash water is injected to control the deposition of ammonium salt during vapor cooling. The separated vapor, containing mostly hydrogen, carbon dioxide and light hydrocarbons, is sent to the Purge Hydrogen Purification unit. The separated liquid is fractionated first in an atmospheric distillation tower where naphtha is removed at the top and light gas oil is recovered from a sidestream stripper. A portion of the atmospheric tower bottoms is recycled as solvent to the coal slurry mix tank while the remaining portion is distilled in a vacuum tower to recover more gas oil product. A sidestream oil product also removed from the vacuum tower is recycled as solvent. The vacuum tower bottoms stream is sent to the Solid/Liquid Separation unit.

The Solid/Liquid Separation unit uses a hydrocarbon solvent to remove heavy hydrocarbon molecules from the vacuum bottoms feed to produce an ash concentrate consisting mostly of ash, unreacted coal, and asphaltenes as well as an extract, which is recycled as solvent to the liquefaction unit. The ash concentrate is combined with fresh coal-water slurry and oxygen and then partially combusted in a Texaco gasifier at about $2600^{\circ} \mathrm{F}$ to produce raw synthesis gas (syngas), which is then quenched and scrubbed to remove entrained solids. A portion of the cooled syngas then goes through a catalytic water-gas-shift reaction section to convert the carbon monoxide to hydrogen. The shifted and unshifted gases then go through an acid gas removal step to remove hydrogen sulfide and most of the carbon dioxide from the gas and produce a pure makeup hydrogen stream and a fuel gas stream. The make-up hydrogen is compressed and fed to the liquefaction reactors, and the fuel gas is combusted in the gas turbine of a combined cycle system to generate steam and power for plant use.

In the Purge Hydrogen Purification unit, the hydrogen to be recycled to the liquefaction reactors is desulfurized and separated from the other gases purged from the product separation unit by using a combination of amine solvent, pressure swing adsorption, and membrane separation. The purified hydrogen is then compressed and recycled. The tail gas, containing mostly light hydrocarbons and a small amount of $\mathrm{C}_{5}-350^{\circ} \mathrm{F}$ fraction, goes to the Light Ends Recovery unit, where it is contacted with naphtha in a series of absorbers and strippers to recover propane as product and lighter hydrocarbons as fuel gas for plant use.

All the acid gases generated in the various process units are combined and fed to a Sulfur Recovery unit, which uses the Claus process to recover elemental sulfur as a by-product. Likewise, all the sour water streams produced in the various process units are first stripped of 
ammonia, which is recovered as a by-product by using the PHOSAM-W process. The stripped water is then further treated in a wastewater treatment unit before being discharged from the plant.

\section{Offsites and Utilities}

The plant includes all the facilities and systems required to support the operation of the process units and the plant in general. Table 15 summarizes the utility sources and requirements throughout the plant. The major offsites and utilities include facilities for

- Relief and blowdown

- Product and catalyst storage

- Product loading and shipping

- Interconnecting piping

- Electrical distribution

- Steam and power generation

- Raw water treatment and supply

- Fire protection

- Sewage and effluent water treatment

- Instrument and plant air supply

- Buildings and plant-wide distributed control.

\section{LIQUEFACTION PLANT COST}

This section presents the cost estimates developed by Bechtel for the commercial integrated liquefaction facility based on the conceptual design discussed earlier.

\section{Cost Estimate Basis}

A preliminary capital cost estimate, with an associated accuracy of $\pm 35 \%$, was developed in fourth-quarter 1994 dollars for a grassroots, Nth plant-type coal liquefaction facility as above. 
Table 15

UTILITY SUMMARY

\begin{tabular}{|c|c|c|c|c|c|c|c|c|}
\hline Plant Section/Area & $\begin{array}{l}\text { Fuel Gas } \\
\text { MMBtu/hr }\end{array}$ & $\begin{array}{c}\text { Electric } \\
\text { Power } \\
\text { kW }\end{array}$ & $\begin{array}{c}\text { Steam } \\
600 \mathrm{psig} \\
720^{\circ} \mathrm{F} \\
1000 \mathrm{lb} / \mathrm{hr}\end{array}$ & $\begin{array}{l}\text { Steam } \\
600 \text { psig } \\
1000 \mathrm{lb} / \mathrm{h}\end{array}$ & $\begin{array}{c}\text { Steam } \\
150 \text { psig } \\
1000 \mathrm{lb} / \mathrm{h}\end{array}$ & $\begin{array}{c}\text { Steam } \\
50 \mathrm{psig} \\
1000 \mathrm{lb} / \mathrm{h}\end{array}$ & $\begin{array}{l}\text { Cooling } \\
\text { Water } \\
\text { gpm }\end{array}$ & $\begin{array}{c}\text { Make-Up } \\
\text { Water } \\
\text { gpm }\end{array}$ \\
\hline \multicolumn{9}{|l|}{ Process Units } \\
\hline Coal grinding \& drying & 547 & 23,882 & & & & & 3,740 & \\
\hline Liquefaction \& prod. separation & 1858 & 37,464 & 7 & (108) & (51) & (64) & 7,505 & \\
\hline Purge hydrogen purification & & 55,730 & & & & 319 & 683 & 167 \\
\hline Light ends recovery & $(3,581)$ & 1,646 & & 327 & & 26 & 11,973 & \\
\hline Solid-liquid separation & 75 & 1,542 & & & 9 & & & \\
\hline Air separation & & 220,935 & & & & & & \\
\hline Coal gasification \& shift conversion & $(485)$ & 17,212 & & $(304)$ & (846) & $(930)$ & 35,261 & 1,313 \\
\hline H2 purification \& compression & & 17,859 & & & 59 & 134 & 13,284 & $\mathscr{B}$ \\
\hline Sour water treatment & & 1,092 & & 259 & 414 & & 54,764 & \\
\hline Sulfur recovery & 55 & 1,276 & & 29 & (16) & 10 & 5,204 & \\
\hline \multicolumn{9}{|l|}{ Utility and Offsites } \\
\hline Steam \& power generation & 3,885 & $(410,375)$ & $(7)$ & (204) & 413 & 499 & 66,100 & 728 \\
\hline Raw and cooling water systems & & 13,264 & & & & & $(198,608)$ & $(8,194)$ \\
\hline Cooling tower evaporation & & & & & & & & 7,944 \\
\hline Sewage/effluent treatment & & 6,304 & & & & 3 & & $(2,150)$ \\
\hline Relief \& blowdown & & $\infty$ & & & & & & \\
\hline Tankage & & 5500 & & & 18 & 4 & 96 & \\
\hline Instrument \& plant air systems & & 2100 & & & & & & \\
\hline Solid waste disposal & & 50 & & & & & & \\
\hline Buildings \& plant lights & & 4500 & & & & & & \\
\hline Potable water system & & & & & & & & 100 \\
\hline Natural gas import & $(2,354)$ & & & & & & & \\
\hline Net total & 0 & 0 & 0 & 0 & 0 & 0 & 0 & 0 \\
\hline
\end{tabular}

() indicates generated quantity 
Bechtel derived the installed plant cost estimate, for the most part, using appropriate cost/capacity curves, ratios, and factors based on detailed data available in-house. Most of the data was previously developed in recent projects involving conceptual design of liquefaction plants of comparable configuration, size, coal feedstocks, and location. The in-house cost data were appropriately adjusted to reflect variation in capacity and process conditions for the respective process units and support systems (offsites and utilities) as well as inflation in material and installation labor costs. A small portion of the estimate was appropriately derived based on equipment specifications (hydrogen and oxygen compression machinery) by factoring from vendor budget-type quotes for the respective equipment.

\section{Installed Plant Capital Cost}

The results of the preliminary capital cost estimation for the conceptual plant are summarized in Table 16 which shows the direct field cost breakdown for the various process units and support systems in the plant. The direct field costs are associated with the permanent physical plant facilities and consist of equipment, bulk material (concrete, structural steel, pipes and fittings, insulation, paint, wire and conduit, and paint), and direct labor costs reflecting the expected productivity level and wage rate for a competitive open-shop construction at the chosen plant location.

As shown in Table 16, the liquefaction and coal gasification process areas represent about $25 \%$ and $13 \%$ of the total direct plant cost, respectively. The liquefaction cost includes the costs for the two-stage liquefaction reactor system as well as the primary product separation and fractionation unit. The gasification cost includes the costs for coal gasification system, shift and gas cooling unit, and make-up hydrogen purification and compression. It does not include the cost for producing and supplying oxygen for gasification, which alone represents about $8 \%$ of the total direct plant cost. All in all, the costs of liquefaction and hydrogen production represent nearly $50 \%$ of the total direct plant cost, with the balance attributed mostly to the hydrogen recycle loop and to generation of power and steam for plant operation.

The indirect field costs shown in Table 16 were estimated as a percentage of the direct labor cost. This percentage reflects Bechtel's experience from other large, grassroots, refinery-type construction projects and takes into consideration the site location, subcontracting level, and construction schedule. These costs are commonly associated with providing temporary construction services (e.g., warehouses, roads, fences, scaffolding, and sanitary facilities), 
Table 16

INSTALLED PLANT CAPITAL COST FOR BASE CASE (Fourth-quarter 1994 dollars)

\begin{tabular}{|c|c|}
\hline Plant Area & $\begin{array}{c}\text { Direct Field Cost } \\
\text { \$MM }\end{array}$ \\
\hline $\begin{array}{l}\text { Process Units } \\
\text { Coal preparation }\end{array}$ & 161.35 \\
\hline Coal liquefaction & 568.70 \\
\hline Light ends recovery & 20.91 \\
\hline Purge $\mathrm{H}_{2}$ purification & 305.77 \\
\hline Solid/liquid separation & 19.82 \\
\hline Coal gasification & 292.66 \\
\hline Air separation & 188.55 \\
\hline Sulfur recovery & 7.06 \\
\hline Ammonia recovery & 31.02 \\
\hline Utilities \& Offsites & \\
\hline Relief \& Blowdown & 4.05 \\
\hline Tankage (storage) & 84.43 \\
\hline Interconnecting piping & 37.40 \\
\hline Product loading \& shipping & 9.21 \\
\hline Ash/slag disposal & 27.01 \\
\hline Catalyst \& chemicals & 0.30 \\
\hline Electrical distribution & 46.50 \\
\hline Steam \& power & 262.33 \\
\hline Water treat. \& supply & 31.37 \\
\hline Fire protection & 12.51 \\
\hline Sewage/effluent treat. & 29.34 \\
\hline Instrument \& plant air & 5.53 \\
\hline Purge \& flush oil system & 9.81 \\
\hline Solid waste management & 3.06 \\
\hline Site development & 70.83 \\
\hline Buildings \& control systems & 66.60 \\
\hline Telecomm. systems & 2.10 \\
\hline $\begin{array}{l}\text { Total direct field cost } \\
\text { Total indirect field cost }\end{array}$ & $\begin{array}{r}2298.21 \\
426.89\end{array}$ \\
\hline Total field cost & 2725.10 \\
\hline Engineering, H.O. \& fee & 231.63 \\
\hline Contingency & 381.52 \\
\hline Total installed plant cost & $\overline{3338.25}$ \\
\hline
\end{tabular}


miscellaneous construction services (e.g., maintenance tools and equipment, material handling, and welder's supplies and testing), construction equipment and tools, and field office.

The engineering, home office, and fee costs shown in Table 16 were estimated based on the complete project. The engineering labor-hours associated with a project of this scope were based on experience from similar types of projects. Labor-hours for home office support services were added as a percentage of the engineering requirements based on historical data from other large refinery-type projects. The total home office labor-hours were priced by using an overall rate that includes a contractor's fee, based on Bechtel's current Houston office experience.

An appropriate project contingency was applied to the estimate to denote the level of confidence in the values ascribed to the elements of the estimate. The amount of this contingency reflects Bechtel's judgment of the cost applied to the complete estimate to yield the most probable cost or the cost at some acceptable probability of underrun/overrun. The addition of this contingency value does not improve the overall accuracy of the estimate, but rather reduces the probability of overrun to a desired level.

Adding the above costs to the total direct field cost results in a total installed Nth plant cost of about $\$ 3400$ million. This total cost does not include costs for land; permits and bonds, natural gas pipeline, process royalties, potable water wells, or setting up remote preassembly yards and facilities.

\section{ECONOMIC ANALYSIS}

To determine the economic incentive for investing the above capital in a project of this scope, a number of operating cost parameters and financial criteria were first established as listed in Table 17. These parameters and criteria are similar, for the most part, to ones used by Bechtel in recent DOE-sponsored direct coal liquefaction studies. The data listed in Table 17 apply to the conceptual configuration and design defined previously and are designated for economic evaluation purpose as the Base Case.

To evaluate the economics for the Base Case, a 25\% equity financing is assumed for the project, and a general inflation rate of $3.1 \%$ is used, but no real price escalation is assumed for either the raw materials or products. In addition, the crude naphtha and gas oil products were valued to have an average selling price equal to that of a crude oil mix to a typical PAD II refinery. Thus, both products were set to have a syncrude premium (SCP) value of 1 . Noting that both the naphtha and gas oil products have not been upgraded by hydrotreating and that a detailed valuation 
Table 17

\section{KEY COST AND FINANCIAL PARAMETERS AND ASSUMPTIONSa}

(Base Case)

\begin{tabular}{ll} 
Cost estimation year & 4 th $Q, 1994$ \\
Plant location & Wyoming \\
ROM Coal price, $\$ /$ ton & 4.50 \\
Natural gas price, $\$ / M M B t u$ & 2.00 \\
Raw water cost, $\$$ per 1000 gal & 2.50 \\
Liquid propane price, $\$ /$ bbl & 12.66 \\
Ammonia by-product price, \$/ton & 206 \\
Sulfur by-product price, $\$ /$ ton & 49 \\
Operating \& maintenance workers & 910 \\
Worker's average pay rate, $\$ / h^{b}$ & 25.9 \\
Project start date & Jan.1995 \\
Years of construction & 4 \\
Years of operation & 25 \\
Depreciation, years & 10 \\
Maintenance material, \% of initial capital & 1 \\
Working capital, \% of revenue & 10 \\
Working capital, \% liquid & 50 \\
Owner's cost, \% of initial capital & 5 \\
Bank interest rate, \% & 8 \\
Federal income tax rate, \% & 34 \\
Percent equity & 25 \\
Desired percent internal rate of return on equity & 15 \\
General inflation, \% & 3.1 \\
Raw material real price escalationc & \\
$\quad$ Coal & 0 \\
Raw water & 0 \\
Natural gas & 0 \\
State tax & 0 \\
Crude oil (PAD II) escalation & 0 \\
Syncrude premium & 1.0 \\
\hline
\end{tabular}

aTotal catalyst and chemicals costs $\$ 84.5$ million/year and $\$ 4.03 / 0 b$ of products (gas, oil, naptha, propane).

bincludes $40 \%$ overhead for benefits, etc.

cAbove general inflation.

A Average selling price of naphtha and gas oil relative to the price of a crude oil mix to a typical PAD II refinery.

analysis was beyond the scope of this study, the SCP chosen for these products were judged reasonable. However, in an actual liquefaction plant, some level of hydrotreating will be required to stabilize these products for shipping, and, in reality, these products are likely to have SCP 
values larger than 1 (the reasons for not including hydrotreating in the conceptual design are discussed earlier).

\section{Product Price for the Base Case}

An economic analysis was performed for the Base Case to determine the crude oil equivalent (COE) price in $\$ / \mathrm{bbl}$ to achieve a desired $15 \%$ return on equity. To perform this analysis, Bechtel used a discounted cash flow spreadsheet model that has been used in several comparable liquefaction studies. The results of this analysis are given in Table 17, which shows that a $\mathrm{COE}$ price of slightly less than $\$ 35 / \mathrm{bbl}$ is required to attain the economic objective.

\section{Economics Sensitivity}

Table 18 also shows the results of an economics sensitivity analysis conducted to determine the sensitivity of the COE price to changes in capital cost and/or pricing caused by financial as well as process-related measures. Seven economic scenarios were evaluated covering different combinations of installed capital cost, raw material price escalation, and product valuation. The results of the analysis show the following:

- A $10 \%$ reduction in capital cost leads to a $\$ 2.23 / \mathrm{bbl}$ drop in COE price.

- Increasing the value of liquid propane by tying its price to crude oil price (using a $\$ 5.72$ margin) leads to about $\$ 0.30$ reduction in COE price. Likewise, increasing the value of gas oil slightly by using a Syncrude Premium factor of 1.02 instead of 1 results in about $\$ 0.50$ reduction in COE price. Of these two methods of correlating the product prices to crude oil price, margins are probably more justifiable than SCP ratios.

- Using the Energy Information Administration (EIA) projected escalation rates for coal, natural gas, and crude oil results in a pronounced reduction in COE price of $\$ 7.63 / \mathrm{bbl}$.

- Combining the above escalation scenario with the above product valuation scenario results in dropping the COE price by $\$ 8.23 / \mathrm{bbl}$.

In addition to the above sensitivity scenarios, Bechtel evaluated two cases resulting from process/plant modifications to the Base Case; both cases involve using synthesis gas (syngas) instead of pure hydrogen in the first stage of liquefaction. These cases are discussed below in more details. 
Table 18

ECONOMIC ANALYSIS RESULTS

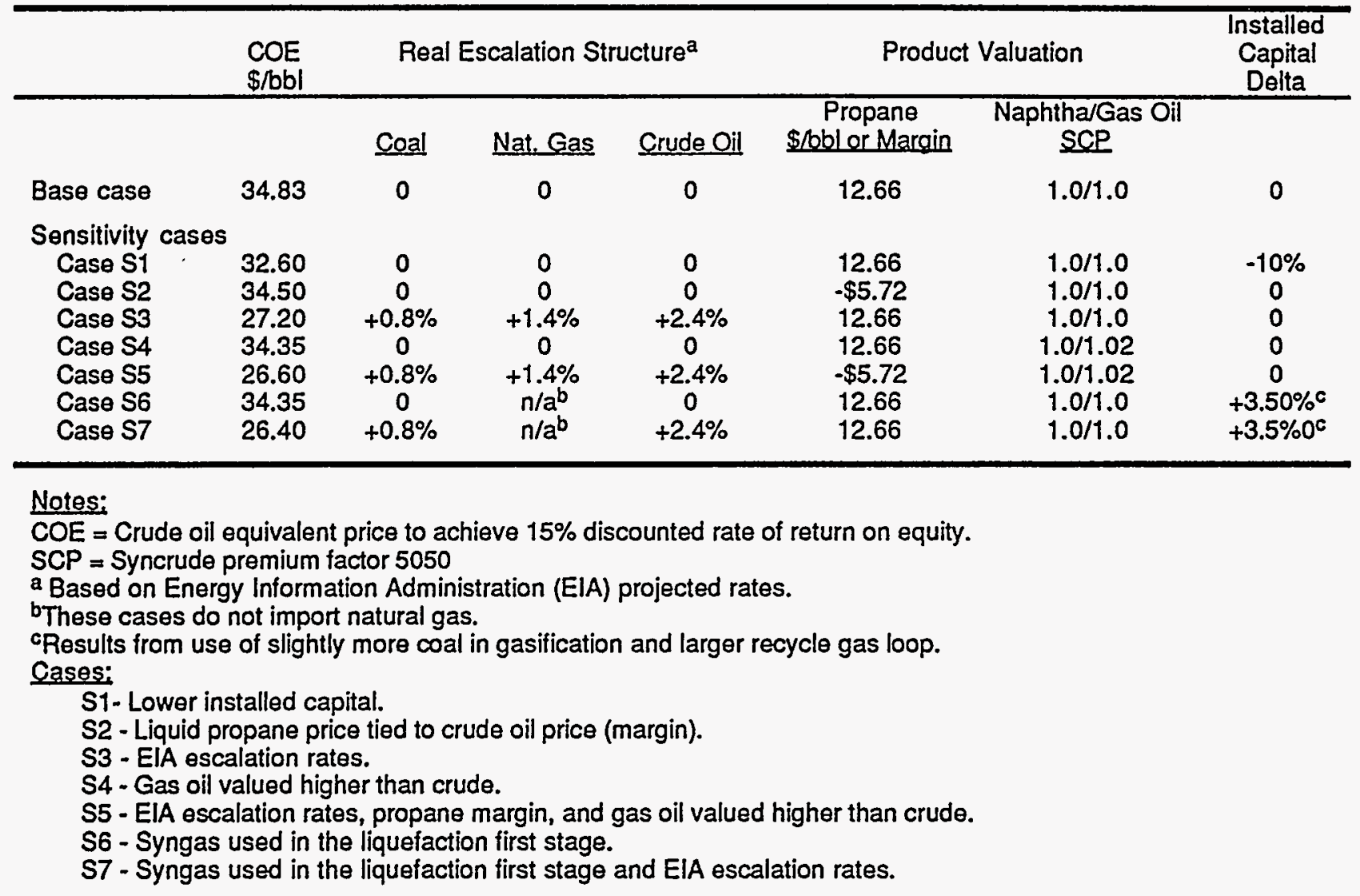

\section{Economic Evaluation of Syngas Case}

SRI provided preliminary results from its laboratory-scale experiments in which syngas (50 vol\% $\mathrm{CO}, 50$ vol\% $\mathrm{H}_{2}$ ) was used in the first reaction stage and hydrogen was used in the second reaction stage. The SRI results show a slightly higher product quality and yield than was achieved in the Base Case where hydrogen was used in both liquefaction stages. Bechtel made a rough assessment of the impact of these results on the plant capital cost and economics developed for the Base Case. The results of this evaluation show the following:

- The $\mathrm{CO}$ shift unit is no longer needed in the gasification process area of the plant. 
- Enough fuel gas is available in the plant to meet all process heating and power generation needs, so natural gas import is no longer required.

- To completely eliminate the $\mathrm{CO}$ shift conversion unit and meet the plant make-up hydrogen requirement, about $8 \%$ more coal will need to be gasified.

- Eliminating the shift conversion unit will increase the complexity of the hydrogen purification unit because of the added difficulty of separating hydrogen from carbon monoxide to produce pure hydrogen for the second-stage reactor.

- The compression requirements (and cost) for purification and compression of make-up hydrogen are reduced.

- Purge hydrogen purification and recycle (gas recycle loop) size increases by about $30 \%$.

- Liquefaction reactor pressure increases by about $25 \%$.

- Phenolics are identified in the products from the liquefaction; accordingly, a process unit is added to recover about 40 tons per day of mixed phenols from the process sour water. The recovered phenol by-product is priced at $\$ 625 /$ ton.

- The production of crude gas oil and liquid propane increase by $8 \%$ and $17 \%$, respectively, while crude naphtha production decreases by about $25 \%$.

- The net effect of the above process variations on the installed plant capital cost is an estimated increase of about 3.5\%. However, this capital cost increase is more than offset by savings in natural gas and gains in revenues from product and byproduct sales as the results for Case S6 in Table 18 show. Compared with the Base Case, the Syngas Case is estimated to reduce the COE price by about $\$ 0.50$. When EIA escalation rates are included, the savings amount to $\$ 0.80$.

Upgrading the naphtha and gas oil by hydrotreating is likely to improve the economics for the Base Case and for all the above sensitivity cases because the plant capital added for hydrotreating is expected to be quickly repaid (short payback period) through potentially significant increases in product values (with SCP ranging from 1.05 to 1.25 ).

\section{FUTURE WORK}

SRI experimental work and Bechtel conceptual design and economic analyses have raised several issues and identified some areas that merit additional work which, we believe, can lead to further improvement of the economics of the liquefaction process concept discussed earlier. Some of the key issues and tasks to be addressed and undertaken in future work are summarized below: 
- Demonstrate the advanced two-stage liquefaction concept in a highly integrated, continuous-flow, bench-scale system that incorporates continuous recycling of process-derived oil. Operation of such system should confirm the quality and stability of the recycle streams at steady state and demonstrated the reliability of continuous interstage separation.

- Characterize more completely the liquid products to better evaluate their upgrading (hydrotreating) requirements and eventual valuation as refinery feeds, or better yet, incorporate hydrotreating in the bench-scale system.

- Focus on achieving operating parameters and conditions that can potentially reduce the cost of the liquefaction reactors and/or the solvent and gas recycle loops without adversely affecting the operability or the product yield and quality. Examples include lowering the operating pressure in the first- and second-stage reactors to, perhaps, 1000 psig or less, lowering the solvent-to-coal ratio to, perhaps, 2.0 or less, and reducing the reaction time to less than 30 minutes.

- Investigate catalyst formulation and operating conditions that can improve distillate oil yield and/or reduce hydrogen consumption.

- Expand the scope of the conceptual design and economic evaluation effort to include developing and updating process models for the critical processing steps in the plant. This process modeling effort will permit quick economic screening that can guide the experimental program; it can also better identify potential synergistic improvements and allow for developing more optimized configuration for an integrated scaled-up facility. The expanded effort should also include a more detailed conceptual design and cost estimation for a commercial integrated plant to confirm the economic premise of the bench-scale liquefaction concept. 


\section{REFERENCES}

1. S. N. Rao, H. D. Schindler, and G. V. McGurl, ACS Fuel Preprints (1988) 33(3), 145-
156. 2. J. M. Lee, O. L. Davies, T. E. Pinkston, and J. R. Gough, ACS Fuel Reprints (1988)
33(3), 157-171.

3. D. Gray and G. Tomlinson, ACS Fuel Preprints (1988) 33(3), 172-179.

4. S. V. Gollakota, J. M. Lee, O. L. Davies, and T. E. Pinkston, DOE Direct Liquefaction Contractors' Review Meeting, Pittsburgh, Pennsylvania, October 1988.

5. R. Neavel, Phil. Trans. R. Soc. Lond. A (1981) 300, 141.

6. E. C. Moroni, ACS Fuel Preprints (1986) 31(4), 294-299.

7. E. M. Suuberg, D. Lee, and J. W. Larsen, Fuel (1985) 64, 1668.

8. G. V. Deshpande, P. Solomon, and M. A. Serio, ACS Fuel Preprints (1988) 33(2), 310.

9. E. C. Moroni, ACS Fuel Preprints (1988) 33(1), 384-386.

10. C.-L. Li, Z., Xu, and B. Gates, Ind. Eng. Chem. Prod. Res. Dev. (1985) 24, 92-97.

11. L. E. Bogan, Jr., D. A. Lesch, and T. B. Rauchfuss, J. Organometallic Chem. (1983) 250,
429-438. 12. B. A. Cowens, R. C. Haltiwanger, and M. R. DuBois, Organometallics (1987) 6, 995-
1004 .

13. K. Vorres, Energy and Fuels (1990) 4, 420-426.

\section{DISCLAIMER}

account of work sponsored by an agency of the United States United States Government nor any agency thereof, nor any of their Government. Neither the United States Government nor anyes any legal liability or responsibility for the accuracy, completeness, or usefulness of an infinge privately owned rights. Referprocess disclosed, or represents that its use would not is, or service by trade name, trademark, ence herein to any specific commercial product, process, or ser imply its endorsement, recommanufacturer, or otherwise does not necessarily constitue or any agency thereof. The views mendation, or favoring by the United States Government or an state or reflect those of the and opinions of authors expressed herein do not

United States Government or any agency thereof. 